\title{
The Gulf of Maine Northern Shrimp (Pandalus borealis) Fishery: a Review of the Record
}

\author{
Stephen H. Clark and Steven X. Cadrin \\ Northeast Fisheries Science Center, Woods Hole Laboratory \\ Woods Hole, MA 02543, USA \\ Daniel F. Schick \\ Maine Department of Marine Resources, Fisheries Research Station \\ West Boothbay Harbor, ME 04575, USA \\ Paul J. Diodati \\ Massachusetts Division of Marine Fisheries, Leverett Saltonstall Building \\ 100 Cambridge St., Boston, MA 02202, USA \\ Michael P. Armstrong and David McCarron \\ Massachusetts Division of Marine Fisheries, Annisquam Laboratory \\ 30 Emerson Ave., Gloucester, MA 01930, USA
}

\begin{abstract}
The Gulf of Maine fishery for northern shrimp (Pandalus borealis) has been a dynamic one, with landings varying greatly in response to resource and market conditions. A directed winter fishery developed in coastal waters in the late-1930s, which expanded to an offshore year round fishery in the late-1960s when annual landings peaked at about 13000 tons in 1969. Landings subsequently declined to very low levels during the mid-1970s as recruitment failed and the stock collapsed, precipitating closure of the fishery in 1977. The resource recovered under restrictive management and was relatively stable at low to moderate levels of exploitation into the 1990s, with several strong year-classes recruiting to the fishery. In the mid-1990s, landings and fishing mortality increased sharply and abundance and recruitment have again declined. Environmental conditions have played an important role in affecting survival and abundance. Stock assessments have consistently shown that poor recruitment is more likely at low levels of spawning stock biomass owing to reduced total egg production. At a stock biomass level of 15 000-20 000 tons, sustainable yields for the Gulf of Maine northern shrimp fishery appear to be $3000-4000$ tons per year under average environmental conditions.
\end{abstract}

Keywords: biology, environment, fishery, Gulf of Maine, management, northern shrimp, Pandalus borealis, stock assessment

\section{Introduction}

The Gulf of Maine northern shrimp (Pandalus borealis) resource has provided an important source of income for New England fishermen. The fishery has been seasonal in nature, peaking in late-winter when ovigerous females move into inshore waters and terminating in spring under regulatory closure. It has therefore been important to fishermen working inshore areas, who otherwise have few options due to seasonal changes in availability of groundfish, lobsters and other species. Figure 1 indicates areas fished, ports and geographic features mentioned in this paper.
Since its inception in the 1930 s the fishery has been a dynamic one. Annual landings have ranged from zero in the mid-1950s to over 12800 tons when the fishery peaked in 1969. Landings again declined to very low levels in the late-1970s with recruitment failure and closure of the fishery but recovered and were relatively stable at around 3 000-4 000 tons from the mid-1980s through the early-1990s. Landings rose to over 9500 tons in 1996, but subsequently declined to 3700 tons in 1998. These fluctuations have closely tracked trends in resource abundance, which appear to have been determined both by exploitation and environmental conditions. 


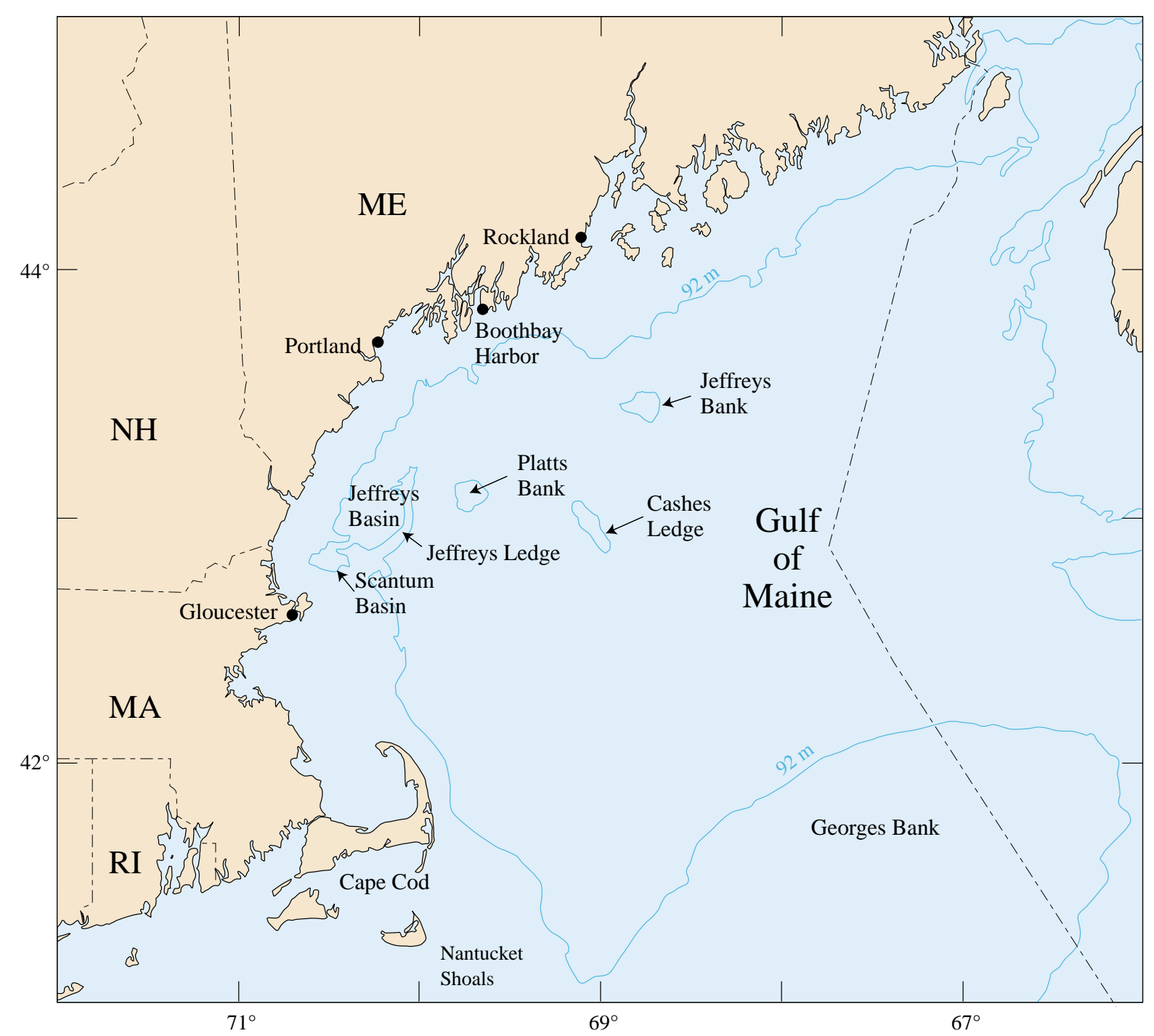

Fig. 1. Gulf of Maine indicating locations and geographical features mentioned in this paper.

Since the early-1970s, this stock has been managed by the participating states of USA (Maine, New Hampshire, and Massachusetts) under the auspices of the Atlantic States Marine Fisheries Commission (ASMFC). The Northern Shrimp Technical Committee (NSTC) of ASMFC, which includes biologists from the above states and the National Marine Fisheries Service (NMFS), is responsible for providing annual stock assessments and management advice. Regulations are promulgated annually based on these assessments and input by industry and other interested parties, and enforced by the participating states.

The purpose of this paper is to review the Gulf of Maine northern shrimp fishery, with particular reference to historical and recent trends in abundance and exploitation and recent developments in assessment and management.

\section{Methods}

Commercial landings and effort data were taken from computer data files of vessel weighout reports collected from dealers and interviews of vessel captains at dockside by NMFS port agents (Burns et al., 1983). This data collection system, which was voluntary in nature, was initiated in 1964. It was replaced by a mandatory logbook based system in 1994. Data for years prior to 1964 were taken from the "Fishery Statistics of the U.S." series. Biological sampling of the catch and dockside interviews have 
been conducted annually by all of the participating states since the mid-1980s; 6 000-13 000 length measurements have been collected each year (Cadrin et al., 1999). Length compositions were weighted by vessel trip landings within each year, state and month combination and expanded by monthly totals by weight to estimate total numbers landed. Biological samples and other data have also been collected on directed shrimp trips in NEFSC and state sea sampling programs. Over 450 trips have been covered since 1991.

In 1968, the State of Maine began to sample standard locations in known concentration areas (Fig. 2) using a shrimp research trawl $(32 \mathrm{~mm}$ stretch mesh codend). This survey was an expanded version of a sampling program implemented in 1966 to collect biological information. The resulting time series (1968-83) proved very useful for estimating trends in abundance, age composition, mortality and recruitment. Northeast Fisheries Science Center (NEFSC) time series are also available since 1968 from spring and autumn multispecies bottom trawl surveys (summer bottom trawl survey cruises have also been conducted in the western Gulf of Maine intermittently.) These surveys employ a stratified random sampling design (Fig. 3) and standard groundfish trawls equipped with roller gear and 12.5 $\mathrm{mm}$ mesh codend liners. These surveys have been found to be very useful for generating indices of stock abundance and biomass. The autumn survey index has been the more reliable, probably due to changes in availability associated with seasonal movements in winter and spring, and has tracked abundance and fishery trends well (Clark and Anthony, 1981; Fig. $4)$. The spring survey has been an important source of biological data, e.g. growth and maturation rates. Azarovitz et al. (MS 1997) provide a complete description of NEFSC bottom trawl surveys and data collection methods used.

In 1984, the Maine survey was replaced by a stratified random survey directed specifically towards northern shrimp (Clark, 1989; Fig. 2). This is a cooperative State-Federal survey conducted by the NSTC each summer. Gear used consists of a modified 4-seam commercial shrimp trawl (32 $\mathrm{mm}$ stretch mesh codend) equipped with "rockhopper" ground gear (Blott et al., MS 1983). This survey has since provided the primary source of fishery-independent data for stock assessments and related research.

For both commercial and survey samples, shrimp were measured from the posterior margin of the eye socket to the posterodorsal margin of the carapace (mid-dorsal carapace length [CL]; Rasmussen, 1953). Measurements were recorded to the nearest $0.5 \mathrm{~mm}$ below (Frechette and Parsons, 1983). Sex was determined according to characteristics of the endopodite on the first pleopod (Rasmussen, 1953), and females further characterized as primiparous or Female I (not having spawned) or multiparous or Female II (having spawned at least once) according to presence or absence of sternal spines (McCrary, 1971).

\section{Results}

\section{Biology}

The biology of northern shrimp in the Gulf of Maine has been studied extensively (Apollonio and Dunton, 1969; Apollonio et al., 1986; Haynes and Wigley, 1969; Rinaldo, 1973, 1981; Stickney, MS 1980,1981; Stickney and Perkins, 1977, 1979; and others). The life cycle of this species in the Gulf of Maine is summarized in Fig. 5. Apollonio et al. (1986) provide an extensive review of biology and distribution as modified by temperature and other environmental parameters; Haynes and Wigley (1969) provide a review of biology, life history and distribution, including comparisons to other populations; papers and reports by Stickney and Perkins examine biology with particular reference to environmental factors affecting recruitment.

In the Gulf of Maine, northern shrimp spawn in offshore waters beginning in late July. By late September, most adult females are ovigerous (Haynes and Wigley, 1969). An inshore migration occurs in autumn, which is apparently temperature-related (Apollonio et al., 1986). Larvae hatch primarily in inshore waters from early February to early April (Stickney and Perkins, 1979; Haynes and Wigley, 1969), after which adult females move immediately offshore. Stickney and Perkins (1977) observed 6 stages of larval development, concluding with a final molt to the juvenile stage (documented in Shumway et al., 1985). Juveniles remain in coastal waters for a year or more before migrating to deeper offshore waters, where they mature as males (Apollonio and Dunton, 1969). In the Gulf of Maine, most individuals mature and function sexually as males at age 2 (2930 months old) and then pass through a series of transitional stages the following winter and spring, finally maturing as females at age 3 (41-42 months old). Maturation, spawning and transition all take place in offshore waters (Apollonio et al., 1986; Haynes and Wigley, 1969). Some females apparently 


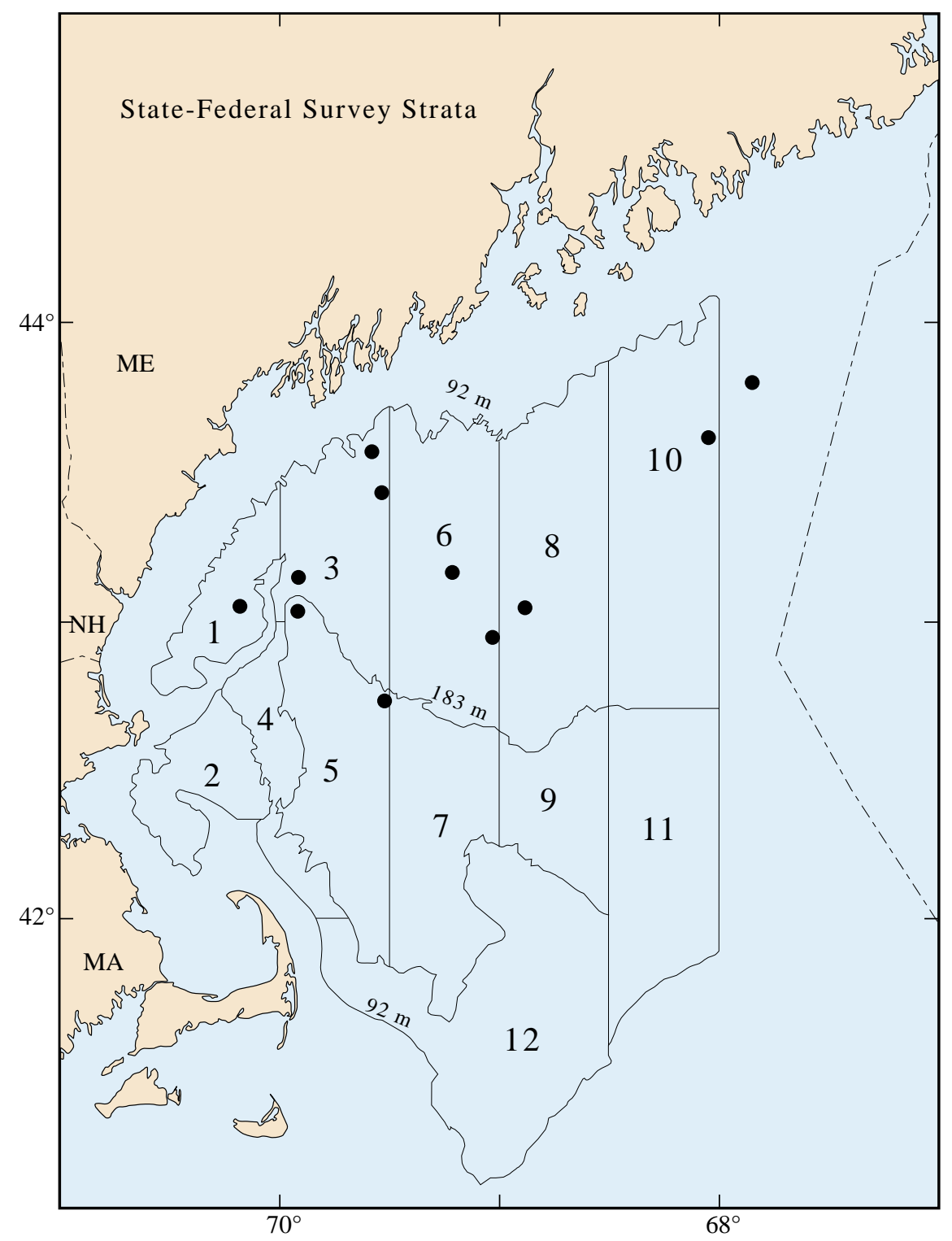

Fig. 2. Strata sampled during the summer State-Federal northern shrimp survey in the western Gulf of Maine. Dots indicate locations of fixed stations sampled in the State of Maine summer survey, 1968-83.

survive to repeat the process in succeeding years, although natural mortality seems to increase sharply following first hatching.

Haynes and Wigley (1969) documented the following categories of shrimp development, all seen in the Gulf of Maine population: two classes of males, immature and mature; four transitional stages, each represented by a molt; and three classes of females. The latter category was further divided as follows: primary, in which male characteristics never appear; secondary, in which male characteristics are repressed shortly after they appear, with individuals maturing as females at age 2; and hermaphroditic, in which individuals go through the normal sequence of maturing first as males at age 2 and then passing through transitional stages to mature as females at age 3. Apollonio and Dunton (1969) found no primary females in their study and Haynes and Wigley (1969) reported only 2 primary females in over 4000 individuals examined. However, about $25 \%$ of age 2 animals were found to mature as secondary females 


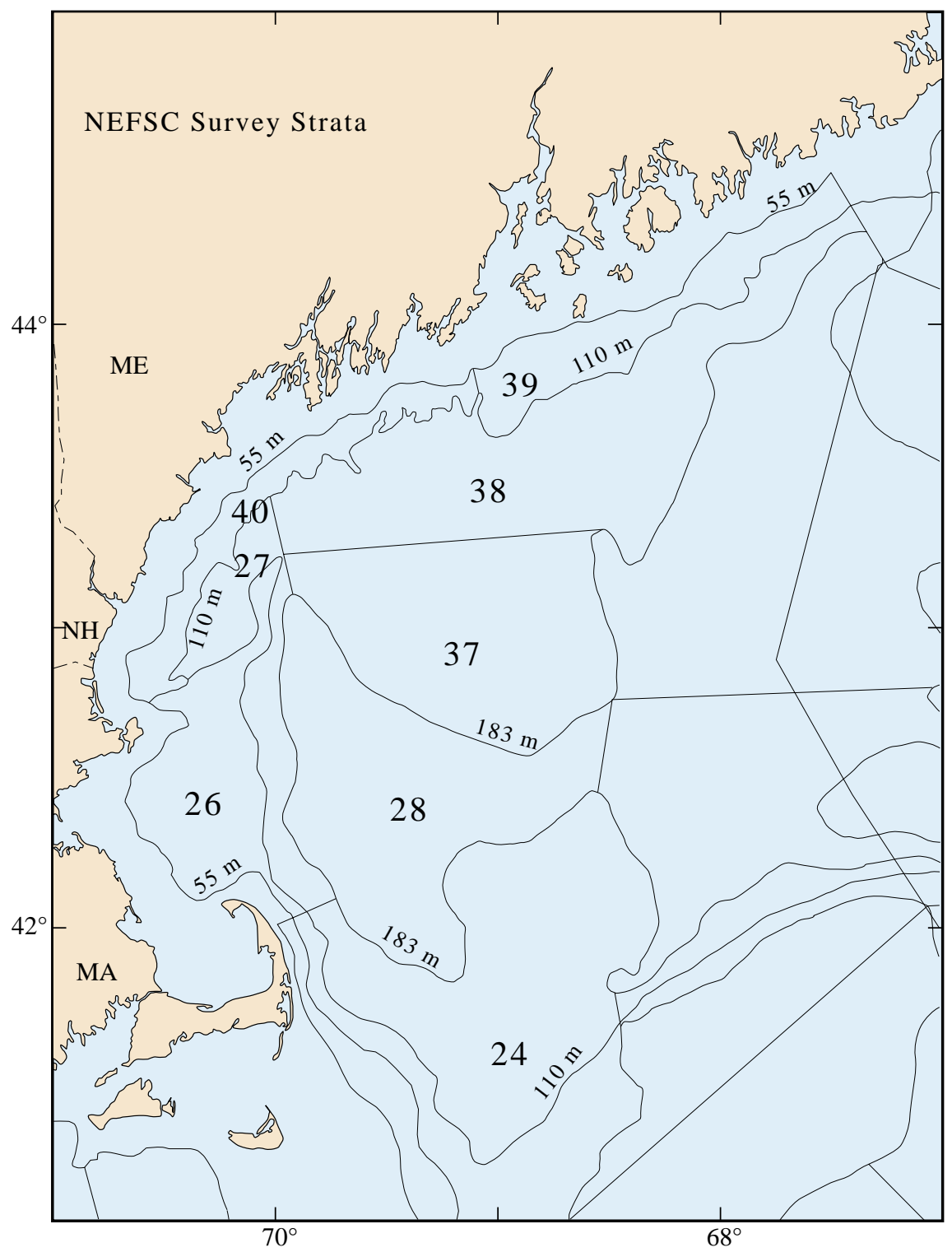

Fig. 3. Strata sampled in the western Gulf of Maine during Northeast Fisheries Science Center (NEFSC) spring and autumn multispecies bottom trawl surveys.

in the latter study; almost all of the remaining animals passed through transition to become females at age 3 . Data collected in more recent years likewise indicates a tendency for at least some of the population to mature as secondary females, e.g. $22 \%$ of the age 2 individuals sampled in Northeast Fisheries Science Center (NEFSC) spring bottom trawl surveys during 197880 were observed to be transitionals or females. There was a clear tendency for early transition to be size dependent, occurring for the larger animals (Clark, MS 1982).
Sample data collected in NEFSC spring and StateFederal summer surveys from 1977 to 1997 indicated an even higher proportion of age 2 (secondary) females in 1977-78 (1975-1976 year-classes) than reported by Haynes and Wigley (1969) (Fig. 6). Annual proportions of secondary females for 1979-83 (197781 year-classes) were on average more comparable to Haynes and Wigley's (1969) data, with most of the population spawning as males at age 2 and undergoing transition the following winter and spring. During these years the population was increasing although 


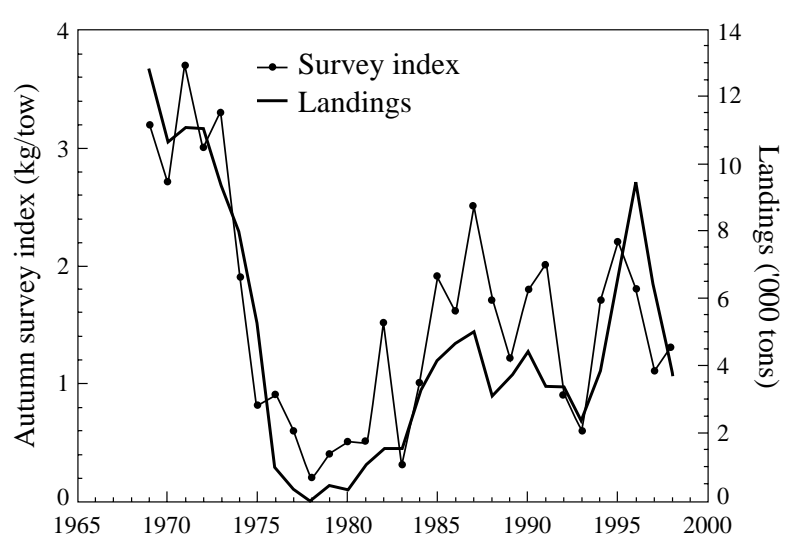

Fig. 4. Northeast Fisheries Science Center (NEFSC) autumn survey index (kg per tow, lagged forwards 1 year) plotted against Gulf of Maine northern shrimp landings, 1968-98.

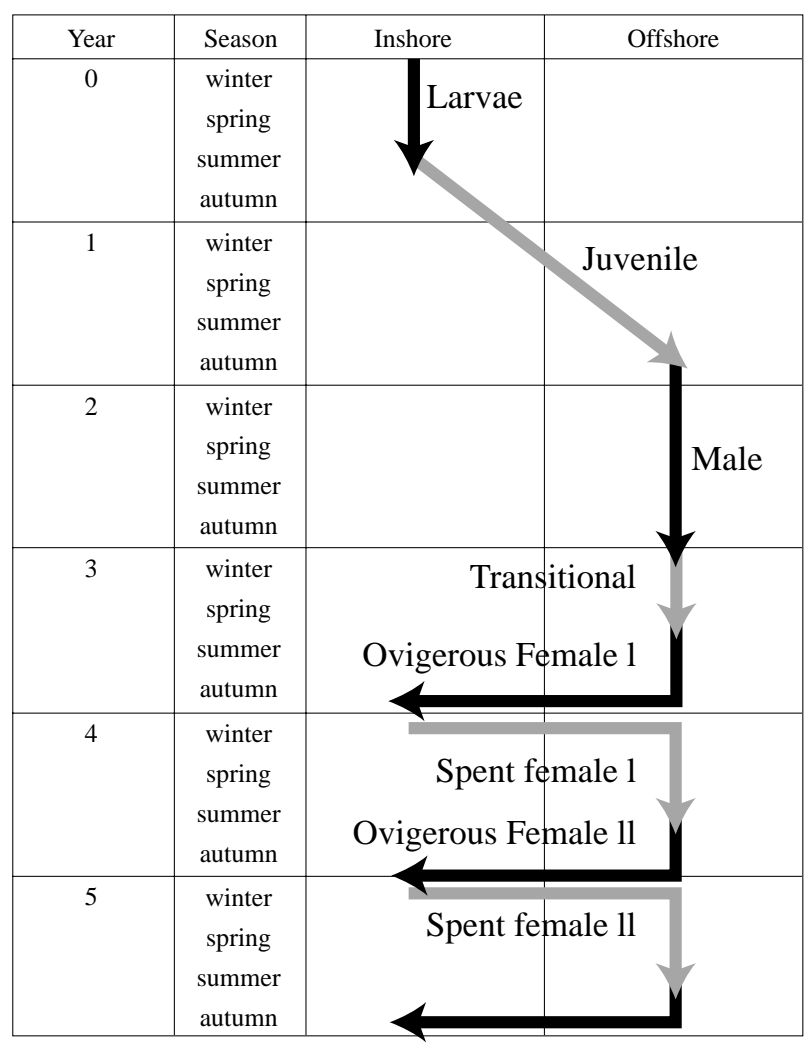

Fig. 5. Life cycle of northern shrimp in the Gulf of Maine (modified from Shumway et al., 1985).

abundance was still very low compared to late-1960s levels. With recruitment of the strong 1982 year-class at age 2 in 1984, the proportion of secondary females declined considerably (Fig. 6), both for the 1982 yearclass and some succeeding year-classes (including the
1987 year-class, which was also a strong one). For these year-classes, a large proportion of the male component did not complete transition the following winter and remained as males at age 3 , while primiparous and multiparous females were much less abundant. The primiparous component likewise was relatively more abundant at age 4 (Fig. 6). After 1992, the pattern generally reverted to that observed from 1979-83, although the proportion of secondary females appeared to be somewhat lower. The trends observed from 1984-92 appear to reflect density dependent effects, particularly for the 1982 and 1987 year-classes.

\section{Growth}

There is considerable information on growth of the Gulf of Maine stock. Haynes and Wigley (1969) presented lengths at age determined from the 196365 NEFSC bottom trawl survey data which provided the following von Bertalanffy growth parameters: $L_{\text {inf }}$ $=32 \mathrm{~mm} \mathrm{CL}, K, 0.46$, and $t_{o},-0.12$ (nonlinear least squares analysis by Terceiro and Idoine, 1990). Rinaldo (1981) reported the following growth parameters from analysis of 1968 data: $L_{i n f}=40.5 \mathrm{~mm}$, $K, 0.29$ and $t_{o},-0.04$. Apollonio et al. (1986) compiled size at age estimates from the 1966-68 survey data and reported rapid growth during the first two years (increments of 12 and $9 \mathrm{~mm} \mathrm{CL}$ in years 1 and 2) followed by a sharp decline to $3 \mathrm{~mm}$ in the third year. This study documented differences in size at age by area and season, which were ascribed to temperature effects, i.e. more rapid growth rates at higher temperatures.

More recent analyses have been based both on statistical separation of modal groups in length frequency distributions and alternative procedures such as Shepherd's (1987) length composition analysis (SRLCA) which match predicted to observed length modes based on a priori growth information. Clark (NEFC, in McInnes, 1986) used Hasselblad's (1966) "normal distribution separator" (Tomlinson, 1971) and visual examination of length frequencies to identify modal groups from NEFSC bottom trawl survey data for 1978-80. Analysis of resulting mean length at age estimates provided the following von Bertalanffy growth parameters: $L_{\text {inf }}=35.2 \mathrm{~mm}, K$, 0.36 , and $t_{\mathrm{o}}, 0.06$. Use of Shepherd's (1987) method on NEFC survey data for 1977-83 provided the following estimates: $L_{i n f}=35.2 \mathrm{~mm}, K, 0.39$, and $t_{o}$, 0.16 . Terceiro and Idoine (1990) subsequently used the SRLCA method to analyze data collected during State-Federal summer survey cruises of 1984-88 and reported $L_{\text {inf }}$ and $K$ values of $33 \mathrm{~mm}$ and 0.32 , 
Age 2
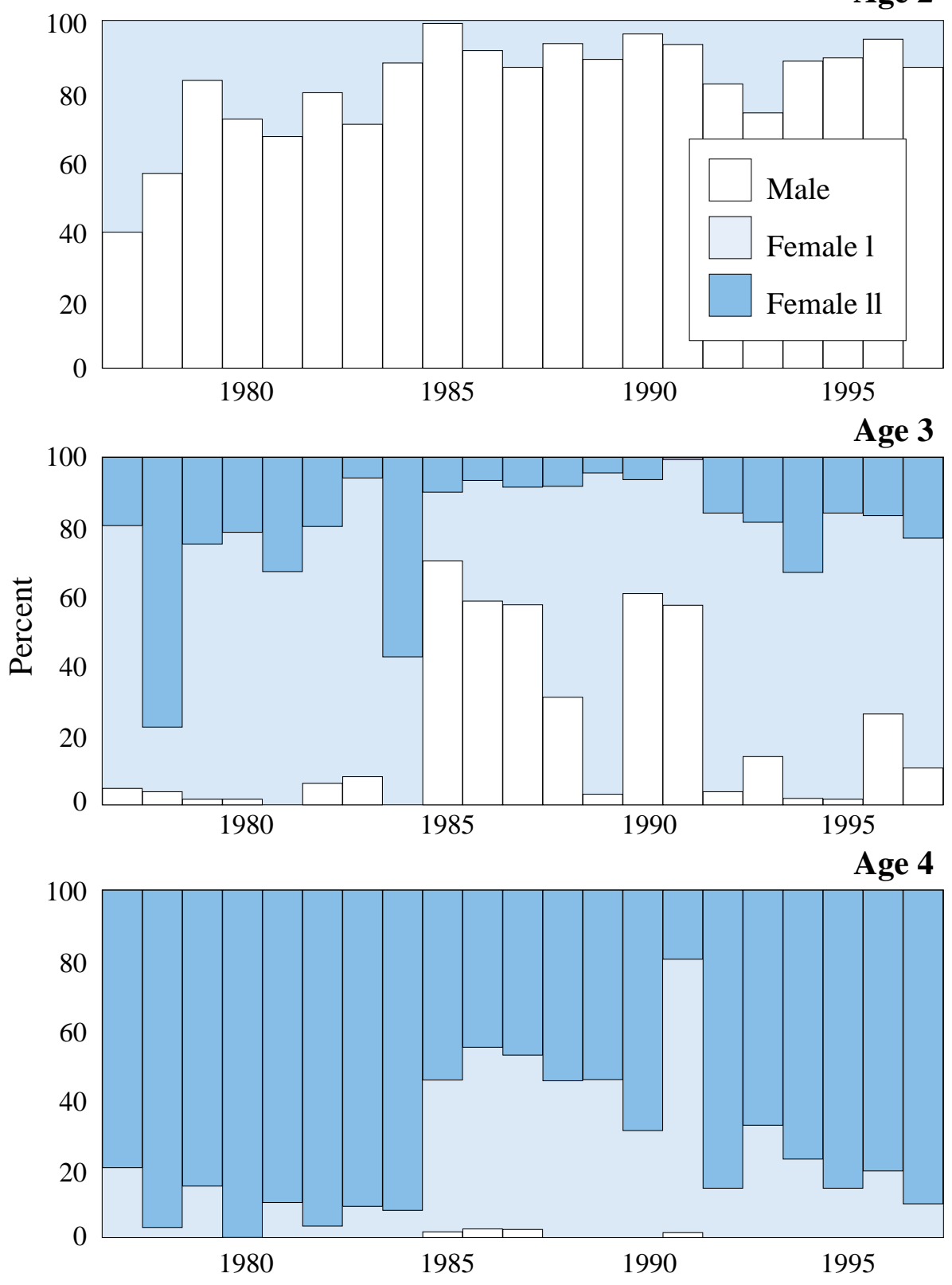

Fig. 6. Sex compositions of Gulf of Maine northern shrimp at assumed age, 1977-97. Females are categorized as Female I (primiparous) or Female II (multiparous).

respectively. Fournier et al. (1991) calculated $L_{\text {inf }}$ and $K$ values of $29.2 \mathrm{~mm}$ and 0.45 , respectively, for the 1984-89 summer survey data using the MULTIFAN maximum likelihood procedure.

Predicted lengths at age from these studies are given in Table 1 and Fig. 7. There is close agreement between the data of Haynes and Wigley (1969) and McInnes (1986) and between the data of Terceiro and
Idoine (1990) and Fournier et al. (1991); but the latter two curves indicate lower mean size at age. Terceiro and Idoine (1990) attributed this to the presence of the strong 1982 year-class in their data set.

\section{Natural Mortality}

Instantaneous natural mortality $(M)$ for this stock has been estimated at 0.25 based on regressions of instantaneous total mortality $(Z)$ estimates from 
TABLE 1. Predicted lengths ${ }^{1}$ at age and von Bertalanffy growth parameters for the Gulf of Maine northern shrimp stock. All curves assume a 1 March birth-date.

\begin{tabular}{rrrrr}
\hline \hline & A & B & C & D \\
\hline 0.5 & 7.9 & 6.8 & 4.9 & 5.9 \\
1.0 & 12.9 & 11.5 & 9.0 & 10.6 \\
1.5 & 16.8 & 15.4 & 12.6 & 14.3 \\
2.0 & 19.9 & 18.7 & 15.6 & 17.3 \\
2.5 & 22.4 & 21.4 & 18.2 & 19.7 \\
3.0 & 24.4 & 23.7 & 20.4 & 21.6 \\
3.5 & 25.9 & 25.6 & 22.2 & 23.2 \\
4.0 & 27.2 & 27.2 & 23.8 & 24.4 \\
4.5 & 28.2 & 28.5 & 25.1 & 25.4 \\
5.0 & 29.0 & 29.6 & 26.3 & 26.1 \\
\hline
\end{tabular}

$\begin{array}{llll}\text { A Haynes and Wigley (1969) } & L_{\text {inf }}=32 \mathrm{~mm}, & K=0.46, & t_{\mathrm{o}}=-0.12 \\ \text { B McInnes (1986) } & L_{\text {inf }}=35.2 \mathrm{~mm}, & K=0.36, \quad t_{\mathrm{o}}=-0.10 \\ \text { C Terceiro and Idoine (1990) } & L_{\text {inf }}=33 \mathrm{~mm}, & K=0.32 \\ \text { D Fournier } \text { et al. }(1991) & L_{\text {inf }}=29.2 \mathrm{~mm}, & K=0.45\end{array}$

${ }^{1}$ Mid-dorsal carapace length (mm).

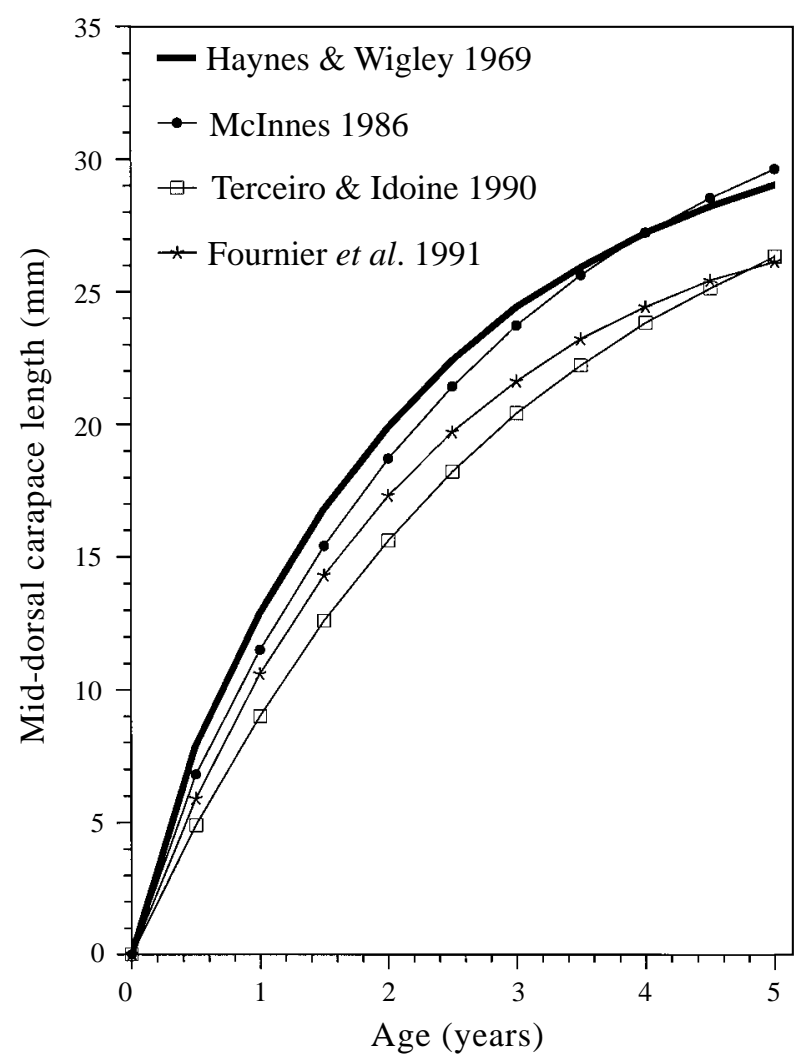

Fig. 7. Growth curves for Gulf of Maine northern shrimp.

research vessel surveys of $1968-72$ on total effort (Rinaldo, 1981). The estimate of $Z$ for 1978 (when the fishery was closed) from State of Maine survey data was 0.17 (Clark, MS 1982). Frechette and Labonte (1981) estimated $M=0.64$ for northern shrimp in the northwest Gulf of St. Lawrence, and a value of 0.75 has been used by the International Council of the Sea (ICES) Pandalus Assessment Working Group in recent years in assessments of European stocks (Anon., MS 1999). Therefore, it appears that $M$ is low in the Gulf of Maine relative to other northern shrimp stocks.

\section{Distribution}

The Gulf of Maine stock is concentrated in the western portion of the Gulf, and from spring through autumn is most common at depths of 90-180 m (Fig. 8). Haynes and Wigley (1969) and Apollonio et al. (1986) reported the species to be most abundant during summer in deeper basins in the southwestern region of the Gulf. This region is characterized by a higher degree of vertical stratification, and colder bottom temperatures, than in coastal areas further east due to reduced tidal mixing (Colton and Stoddard, 1973, in McInnes, 1986). Abundance in the eastern Gulf of Maine is relatively low and there is no evidence of a relationship between the Gulf of Maine population and populations on the Scotian Shelf. For management purposes the Gulf of Maine population is considered to be a single unit stock (Clark and Anthony, 1981).

Temperature, substrate, salinity and depth have all been considered as factors governing the distribution of pandalid shrimp (Shumway et al., 

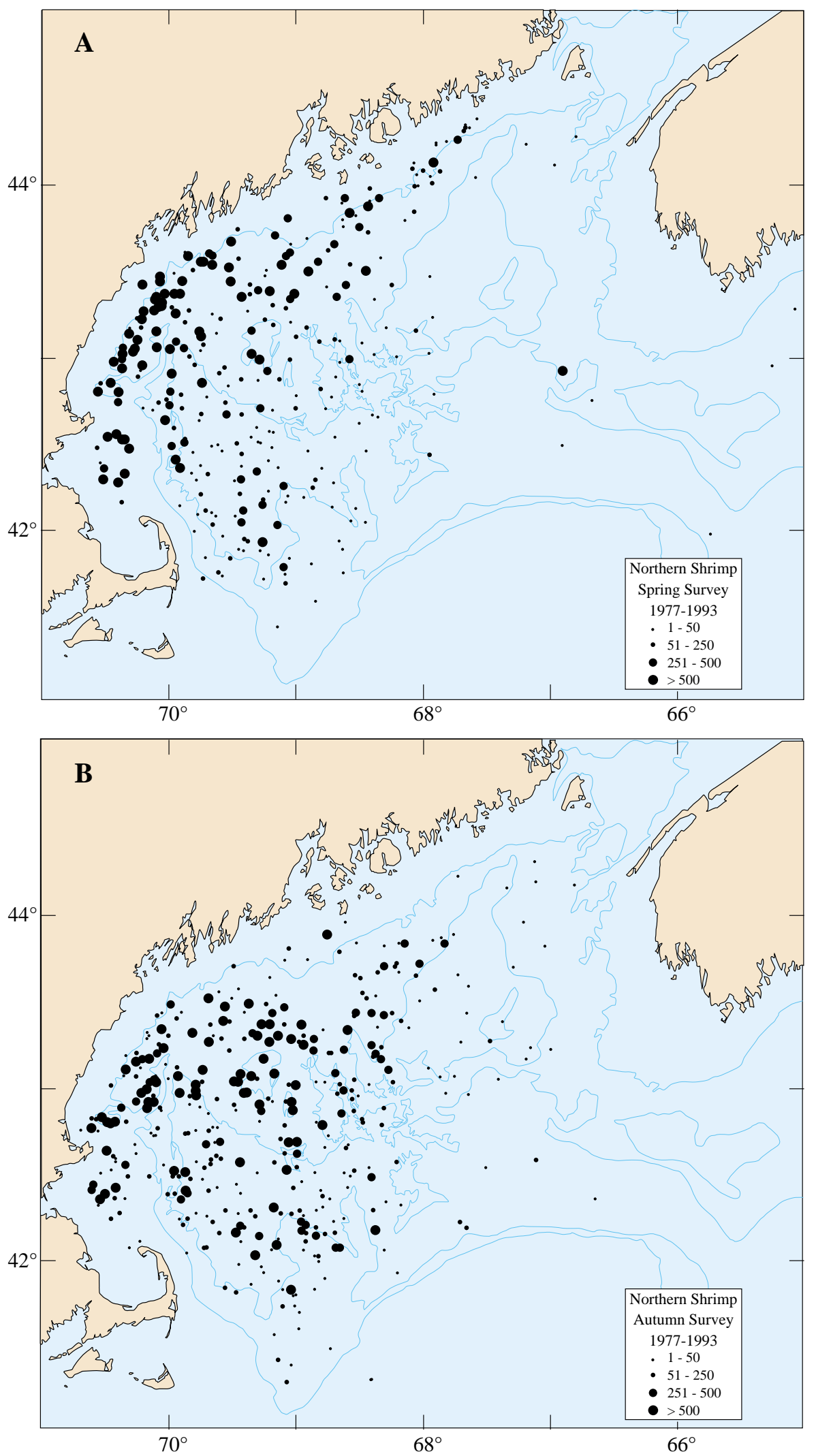

Fig. 8. Observed distributions of northern shrimp (numbers per tow) in Northeast Fisheries Science Center (NEFSC) spring (A) and autumn (B) bottom trawl surveys, 1977-93. 
1985). Haynes and Wigley (1969) reported a close association between Pandalus borealis and finegrained sediments such as clay, silt, silty sand and glacial till with moderate to high amounts of organic carbon. These authors felt that temperature could restrict distribution of the species to areas north of the Georges Bank-Cape Cod region, but did not consider temperature (or salinity) to be limiting to distribution of the species in the Gulf of Maine. Schick (MS 1991) similarly found much higher densities of shrimp in Jeffreys Basin over soft bottom as compared to hard bottom areas in underwater video line transect studies. Observed densities were also considerably higher than observed in similar studies further east (Langton and Uzmann, 1989; Rowe et al. 1975, in Schick MS 1991). Apollonio et al. (1986) studied effects of temperature on biology and distribution of the Gulf of Maine population extensively and considered temperature to be the overriding factor. They considered that the submarine basins of the southwestern Gulf, with their deep cold areas protected by thermal stratification during summer, provided the best habitat for the species in the Gulf of Maine. Both annual and seasonal distribution were believed to be temperature driven, with seasonal movements in relation to temperature being an important component of reproductive strategy. They noted that the correlations of shrimp abundance and high organic content reported in other studies could be coincidental rather than causal, since colder water and fine sediments both tend to be trapped in such habitats.

More recent survey data support the overriding influence of temperature upon the distribution of this species in the Gulf of Maine. Spring and autumn distributions (Fig. 8) appear strongly dependent upon local temperature conditions, with an inshore shift evident in spring where temperatures are coldest; and data from State-Federal summer surveys indicate a very strong preference for bottom temperatures between $4-6^{\circ} \mathrm{C}$, the coldest observed range in the survey region at this time of year (Clark et al., 2000). Within this range, the species was found to be most common on fine-grained sediments (Clark et al., 2000). Highest concentrations, however, were clearly defined by the $6^{\circ} \mathrm{C}$ isotherm; and to the east of Cashes Ledge and Jeffreys Bank, where temperatures tended to exceed $6^{\circ} \mathrm{C}$, abundance was observed to decline sharply, even in areas where bottom conditions are favorable.

\section{The Fishery}

Initial development of the fishery has been reviewed by several authors, (Scattergood, 1952; Bruce, 1971; Wigley, 1973 and others). Rathbun (1883, in Scattergood, 1952) was apparently the first to note the presence of harvestable concentrations of northern shrimp in New England waters and to venture the opinion that they could support an important industry when knowledge about their distribution and appropriate gears became available. Introduction of trawl gear in the early-1900s provided a viable option for harvesting shrimp, but since effort was directed towards groundfish with large mesh trawls catches were initially light.

Organized attempts to establish a fishery did not begin until the late-1920s, when the General Seafoods Corporation chartered vessels and provided gear to conduct exploratory surveys. This was followed by a 1936 survey aboard R/V Atlantis under the direction of the renowned Norwegian scientist and shrimp fishery expert Johan Hjort and subsequent cooperative studies by the U.S. Bureau of Fisheries and industry which demonstrated the feasibility of a commercial fishery (Walford, 1948; Scattergood, 1952).

The fishery formally began in 1938, when 13 draggers began fishing out of Portland, Maine. From the 1930 s to the 1950 s almost all of the landings were by Maine vessels from Portland and smaller Maine ports further east. This was an inshore winter fishery, primarily from January-April, directed towards ovigerous females in inshore waters (Scattergood, 1952). (Efforts were made to locate commercial concentrations in summer of 1938 , but these were unsuccessful). Very small landings were also made by Massachusetts vessels during these years. As demand was initially light (primarily for fresh consumption and home canning) landings were initially small; but with the opening of several canneries in Maine and introduction of quick freezing techniques, demand rose and landings increased sharply to a peak of 264 tons in 1945 (Table 2, Fig. 9 ). Landings then declined with declining abundance into the 1950s and during 1954-57 no commercial landings of shrimp were recorded.

In the late-1950s the fishery began to recover, due to the efforts of commercial interests in Portland, Maine and presumably to improving resource conditions. Initially, landings were processed and sold 
TABLE 2. Commercial landings (tons) of northern shrimp in the western Gulf of Maine, 1938-98.

\begin{tabular}{|c|c|c|c|c|c|}
\hline \multirow[b]{2}{*}{ Year } & \multirow[b]{2}{*}{ Maine } & \multirow[b]{2}{*}{ New Hampshire } & \multirow[b]{2}{*}{ Massachusetts } & \multicolumn{2}{|c|}{ Totals } \\
\hline & & & & Annual & Seasonal ${ }^{1}$ \\
\hline 1938 & 37.4 & 0.0 & 10.5 & 47.9 & - \\
\hline 1939 & 8.2 & 0.0 & 16.3 & 24.5 & - \\
\hline 1940 & 3.0 & 0.0 & 1.2 & 4.2 & - \\
\hline 1941 & 25.9 & 0.0 & 0.0 & 25.9 & - \\
\hline 1942 & 49.5 & 0.0 & 0.9 & 50.4 & - \\
\hline 1943 & 132.3 & 0.0 & 1.5 & 133.8 & - \\
\hline 1944 & 207.7 & 0.0 & 1.8 & 209.5 & - \\
\hline 1945 & 263.5 & 0.0 & 0.5 & 264.0 & - \\
\hline 1946 & 73.3 & 0.0 & 2.0 & 75.3 & - \\
\hline 1947 & 88.0 & 0.0 & 0.2 & 88.2 & - \\
\hline 1948 & 12.3 & 0.0 & 0.0 & 12.3 & - \\
\hline 1949 & 4.5 & 0.0 & 0.0 & 4.5 & - \\
\hline 1950 & 3.4 & 0.0 & 0.1 & 3.5 & - \\
\hline 1951 & 20.4 & 0.0 & 5.9 & 26.3 & - \\
\hline 1952 & 47.1 & 0.0 & 0.2 & 47.3 & - \\
\hline 1953 & 17.3 & 0.0 & $0.0^{2}$ & 17.3 & - \\
\hline 1954 & 0.0 & 0.0 & 0.0 & 0.0 & - \\
\hline 1955 & 0.0 & 0.0 & 0.0 & 0.0 & - \\
\hline 1956 & 0.0 & 0.0 & 0.0 & 0.0 & - \\
\hline 1957 & 0.0 & 0.0 & 0.0 & 0.0 & - \\
\hline 1958 & 2.3 & 0.0 & 0.0 & 2.3 & - \\
\hline 1959 & 5.5 & 0.0 & 2.3 & 7.8 & - \\
\hline 1960 & 40.4 & 0.0 & 0.5 & 40.9 & - \\
\hline 1961 & 30.5 & 0.0 & 0.3 & 30.8 & - \\
\hline 1962 & 159.5 & 0.0 & 16.2 & 175.7 & - \\
\hline 1963 & 244.3 & 0.0 & 10.4 & 254.7 & - \\
\hline 1964 & 419.4 & 0.0 & 3.1 & 422.5 & - \\
\hline 1965 & 941.3 & 0.0 & 8.0 & 949.3 & - \\
\hline 1966 & 1737.8 & 18.1 & 10.5 & 1766.4 & - \\
\hline 1967 & 3141.2 & 20.0 & 10.0 & 3171.2 & - \\
\hline 1968 & 6515.2 & 43.1 & 51.9 & 6610.2 & - \\
\hline 1969 & 10993.1 & 58.1 & 1773.1 & 12824.3 & - \\
\hline 1970 & 7712.8 & 54.4 & 2902.3 & 10669.5 & - \\
\hline 1971 & 8354.8 & 50.8 & 2724.0 & 11129.6 & - \\
\hline 1972 & 7515.6 & 74.8 & 3504.5 & 11094.9 & - \\
\hline 1973 & 5476.6 & 59.9 & 3868.2 & 9404.7 & - \\
\hline 1974 & 4430.7 & 36.7 & 3477.3 & 7944.7 & - \\
\hline 1975 & 3177.2 & 29.4 & 2080.0 & 5286.6 & - \\
\hline 1976 & 617.3 & 7.3 & 397.8 & 1022.4 & - \\
\hline 1977 & 142.1 & 2.2 & 236.9 & 381.2 & - \\
\hline 1978 & $0.0^{2}$ & 0.0 & 3.3 & 3.3 & - \\
\hline 1979 & 32.8 & 0.0 & 405.9 & 438.7 & - \\
\hline 1980 & 69.6 & 6.3 & 256.9 & 332.8 & - \\
\hline 1981 & 530.0 & 4.5 & 539.4 & 1073.9 & - \\
\hline 1982 & 883.0 & 32.8 & 658.5 & 1574.3 & 1530.2 \\
\hline 1983 & 1029.2 & 36.5 & 508.2 & 1573.9 & 1397.1 \\
\hline 1984 & 2564.7 & 96.8 & 565.3 & 3226.8 & 2950.7 \\
\hline 1985 & 2957.0 & 207.4 & 1030.5 & 4194.9 & 4130.9 \\
\hline 1986 & 3407.2 & 191.1 & 1085.7 & 4684.0 & 4635.0 \\
\hline 1987 & 3534.2 & 152.5 & 1338.7 & 5025.4 & 5253.2 \\
\hline 1988 & 2272.5 & 173.1 & 632.7 & 3078.2 & 3031.3 \\
\hline 1989 & 2544.8 & 314.3 & 751.6 & 3610.7 & 3315.4 \\
\hline 1990 & 2962.1 & 447.3 & 993.4 & 4402.8 & 4661.6 \\
\hline 1991 & 2431.5 & 208.3 & 737.7 & 3377.5 & 3571.4 \\
\hline
\end{tabular}


TABLE 2. (Continued). Commercial landings (tons) of northern shrimp in the western Gulf of Maine, $1938-98$.

\begin{tabular}{lccccc}
\hline \hline Year & Maine & New Hampshire & Massachusetts & \multicolumn{2}{c}{ Totals } \\
\hline 1992 & 2990.4 & 100.1 & 291.7 & 3382.2 & 3443.6 \\
1993 & 1563.1 & 441.2 & 300.3 & 2304.6 & 2142.9 \\
1994 & 2815.8 & 521.0 & 381.9 & 3718.7 & 2914.8 \\
1995 & 5399.2 & 752.3 & 677.7 & 6829.2 & 6466.4 \\
1996 & 8169.6 & 767.5 & 587.4 & 9524.5 & 9166.1 \\
1997 & 5457.1 & 570.1 & 321.7 & 6348.9 & 7079.1 \\
1998 & 3050.8 & 402.4 & 223.1 & 3676.3 & 4174.4 \\
\hline
\end{tabular}

1 Landings totals by season, for seasons as promulgated by ASMFC under its 1981 Statement of Policy. Seasons are designated by the year covered by the winter-spring fishery, e.g. the 1983 seasonal total includes landings from the season promulgated from 15 December 1982 to 30 April 1983.

2 Less than 0.1

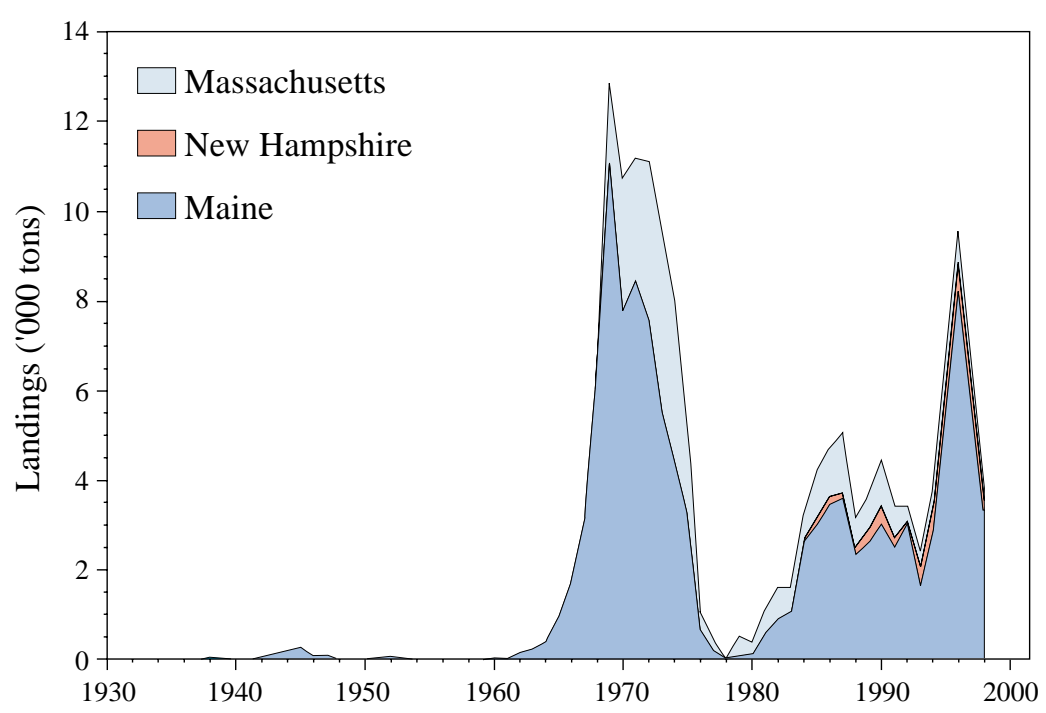

Fig. 9. Annual landings of Gulf of Maine northern shrimp by State, 1930-98.

locally or shipped south. Again, however, domestic demand increased rapidly and a strong European market also developed during the mid-1960s (Bruce, 1971). Yet another factor in the rise of the fishery was the declining abundance of whiting or silver hake (Merluccius bilinearis) in the late-1960s (Kallio, MS 1973). As demand grew the number of vessels in the fishery rose from 32 in 1964 to over 300 in 1970 (MacIsaac and Diodati, 1978). Many of these were larger draggers in the 18-21 $\mathrm{m}$ range capable of fishing in deeper areas up to and over $183 \mathrm{~m}$. Numerous small vessels, primarily lobster boats operating from smaller ports east of Portland, also entered the fishery, and as the decade progressed their landings became a major seasonal component of the total (Bruce, 1971). These vessels fished very close to shore in wintertime, often in estuaries or at the mouths of harbors. Portland vessels (usually larger draggers) tended to fish further offshore to the southeast of Portland; but they too focused primarily on adult females in wintertime. Typically, the Maine fishery declined rapidly with offshore movement of females in late winter and was insignificant from May through November.

Landings increased dramatically throughout the 1960s to a peak of 12800 tons in 1969, of which 11000 tons were taken by Maine vessels (Table 2, Fig. 9). New Hampshire vessels entered the fishery in 1966, but throughout the 1960s and 1970s New Hampshire landings were minor.

Landings by Massachusetts vessels were insignificant until 1969, when efforts were made to stimulate the Gloucester fishery. A number of 
Gloucester draggers began to fish during summer of 1969 , and by July of 1970 approximately 25 draggers were involved (Bruce, 1971). Apparently due at least in part to declining abundance of whiting (Kallio, MS 1973) the Gloucester fishery developed rapidly, with landings increasing from $14 \%$ of the Gulf of Maine total in 1969 to over $40 \%$ in $1974-75$. In contrast to the historical wintertime Maine fishery, these vessels fished continually throughout the year and made significant catches during summer months. From 1969 to $1974,60 \%$ of the Gloucester total was taken from May to November. At this time, Maine vessels began to fish more intensively in summer as well, but May to November landings were only $10 \%$ of the Maine total during these years.

The summer fishery which developed in the early1970s was significant in that it impacted shrimp of all age groups in deeper offshore areas, with substantive increases in fishing mortality on younger shrimp. Vessels intensively exploited Scantum and Jeffreys Basins and other areas north and east of Gloucester, occupied by all age classes including concentrations of immature (age 1) and mature male (age 2) shrimp (MacIsaac and Diodati, 1978). Sampling of commercial landings during these years indicated high proportions of age 1 and 2 shrimp in spring and summer (e.g. $40-50 \%$ of the landed total by number from April-June, increasing to $70-80 \%$ for July-September during 1973-74). As the total tonnage landed in these months had become significant ( $40 \%$ of the $1973-74$ total) it appears likely that the summer fishery was a major contributor to increases in fishing mortality during these years and subsequent recruitment failure. Sampling in 197374 revealed that about 600 million shrimp were taken from the 1972 year-class during these years (212 million and 384 million at ages 1 and 2, respectively). The average number of recruits entering the fishery annually from 1984-98 was 800 million shrimp, based on Catch-Survey (C-S) modeling discussed below. An additional complicating factor was by-catch and potential discard of shrimp in directed operations for whiting, another small-mesh trawl fishery, in summer and autumn (MacIsaac and Diodati, 1978). The distribution of whiting overlaps that of shrimp during the summer months, and many fishermen have used the same gear to fish for both species. Shrimp landings from directed whiting trips appear to have been minor in comparison to landings from directed shrimping operations; but little sea sampling data are available to verify the extent to which these trips were "directed" and more importantly, the extent of shrimp discard in the whiting fishery is unknown. Concerns about resource impacts and losses in yield-per-recruit and product quality led to closure of the fishery in summer of 1975 and again in 1976 from mid-April through December (see Management below).

Total annual landings averaged 11000 tons from 1970 to 1972 and then declined rapidly until 1977 when only 400 tons were landed (Table 2, Fig. 9). The fishery was then closed from mid-May of 1977 to February 1979. During the 1979 winter fishery (February-March) only 400 tons were landed, almost all by Massachusetts vessels.

Since the mid-1970s collapse, fishing effort has been restricted to December through May (see Management below). Seasonal shifts in effort and in catch composition have been apparent, because of the fishery's primary focus on ovigerous females. In December, effort was concentrated between 10-20 naut. miles from the coast, but in January and February a pronounced shift into shoaler waters occurred as ovigerous females move inshore and smaller vessels entered the fishery. Much of this effort occurred within 5 naut. miles of the coast. In late winter and spring, effort again shifted offshore, to 20-30 naut. miles from the coast or further, as female shrimp moved offshore. Length compositions determined from sampling of commercial landings reflect these trends, with increased percentages of males and transitional stages evident in spring (Fig. 10).

Since 1980, landings and effort have fluctuated considerably in response to recruitment from the strong 1982, 1987 and 1992 year-classes. Annual landings peaked at 5000 tons and 4400 tons in 1987 and 1990, respectively, and then dropped to 2300 tons in 1993. Landings then increased to 9500 tons in 1996 before declining to 3700 tons in 1998. As has been true historically most of the catch in these years were taken by Maine vessels (76\%) with Massachusetts vessels accounting for most of the remainder (17\%). Numbers of participating vessels have fluctuated considerably, increasing to $300-400$ vessels in some years. In 1996, about 350 vessels were active in the fishery, but this number dropped to 260 vessels during 1998.

Participation in Maine has been based both on potential economic returns between lobsters, scallops, groundfish and shrimp and vessel size. Maine participants have succeeded by being versatile, re-rigging their vessels in response to costs, ex-vessel prices and availability of target species. When shrimp are available in sufficient quantity and ex-vessel prices 

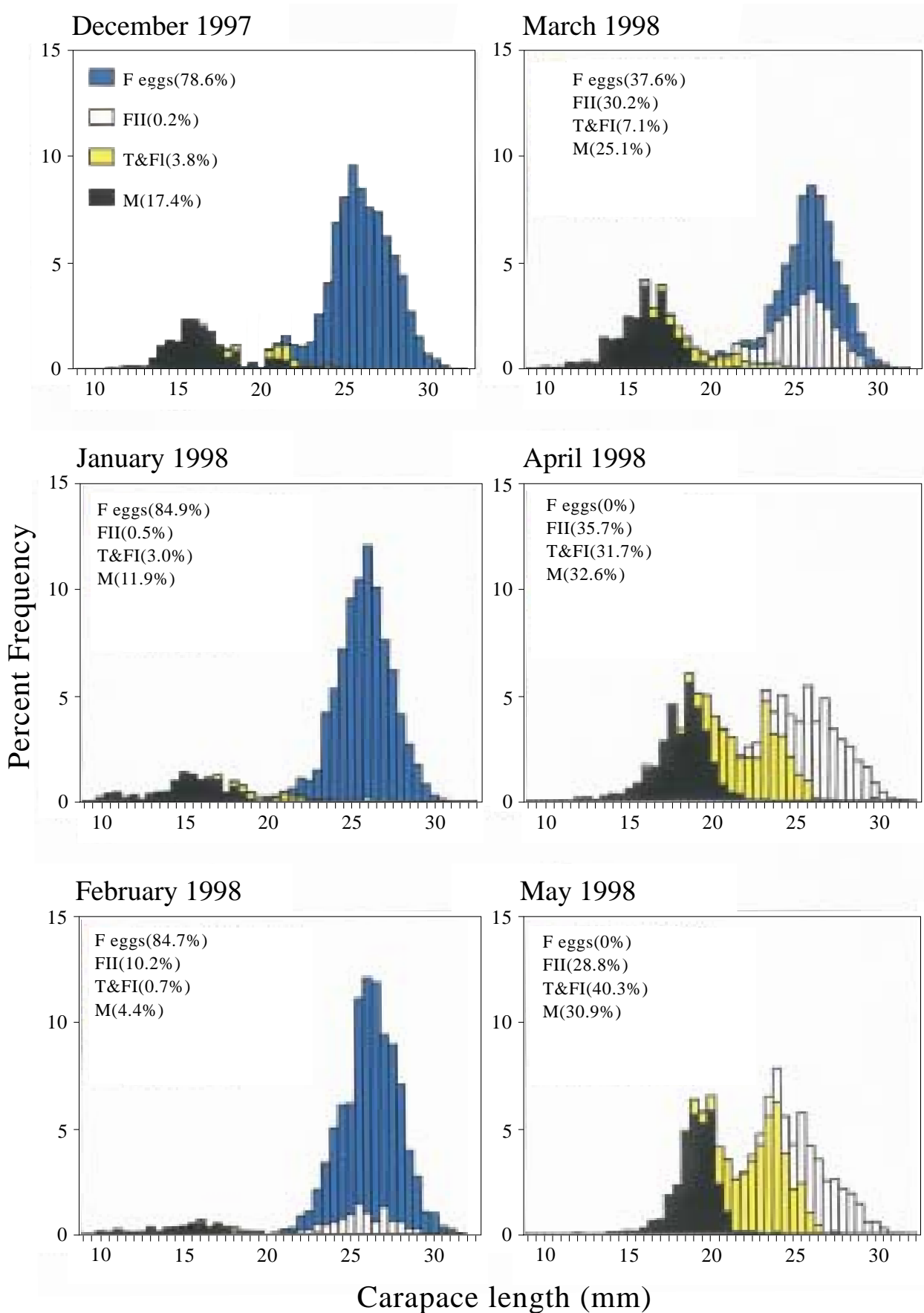

Fig. 10. Length compositions (mid-dorsal carapace length, mm) of Gulf of Maine northern shrimp derived from sampling of Maine commercial landings, December 1997-May 1998. ( $\mathrm{M}=$ males; T \& F I = transitionals and Female I (primiparous females); F II = Female II (multiparous females); and F eggs = ovigerous females.

are high, they are attractive to larger numbers of the more versatile vessels and total effort may increase dramatically. Maine vessels have continued to operate primarily out of Portland and smaller ports further east.
New Hampshire landings increased rapidly in the mid-1980s and vacillated around an average of $10 \%$ of the total through the $1990 \mathrm{~s}$, exceeding those of Massachusetts in some years. New Hampshire's fleet fishes out of only three small ports. 
The Massachusetts fishery expanded rapidly in the 1980s; landings surpassed the Maine total from 1979 to 1981 and remained significant until 1992. The number of participating vessels increased to about 80 by the end of the decade, but then declined, with the exception of a brief resurgence in 1995 and 1996. The decline in recent years reflects a number of factors including fleet reductions associated with severe restrictions in the groundfish fishery and federal "buyback" programs, recent declines in abundance and quality of shrimp with concomitant poor prices, and availability of other options during the shrimp season. Less than 30 vessels participated during the 1998 fishing season, and Massachusetts accounted for only $6 \%$ of the total during that year. As was the case for earlier years shrimp have been landed primarily in Gloucester and smaller ports further north.

In the late-1980s a spring fishery developed off Nauset, Cape Cod, which harvested large female shrimp. This fishery was initially prosecuted by large draggers from Gloucester but in later years only smaller vessels from Cape Cod have been involved. This fishery did not occur in 1998 due to low abundance.

A wide variety of vessels were used in the fishery during the 1960s and 1970s (Bruce, 1971; Wigley, 1973). The predominant type among larger vessels at least initially, appears to have been side-rigged trawlers in the $14-23 \mathrm{~m}$ range. Most of these vessels had been built for groundfishing and required little if any modification for the shrimp fishery. Numerous vessels were also built or purchased elsewhere for use in this fishery, such as Gulf Coast shrimp trawlers. Such vessels, if double-rigged, Gulf of Mexico style when purchased, were modified as side or stern trawlers. Bruce (1971) describes an additional class of vessels in the 14-16 m range, expressly built for shrimp fishing, rigged for either side or stern trawling. A large number of lobster vessels with a variety of rigging arrangements were also active seasonally in shoaler waters. During the 1980s and 1990s, side trawlers either re-rigged to stern trawling, or retired from the fleet. Currently, the shrimp fleet is comprised of lobster vessels in the 9-14 m range that re-rig for shrimping, small to mid-sized stern trawlers in the $12-17 \mathrm{~m}$ range, and larger trawlers primarily in the $17-24 \mathrm{~m}$ range.

The otter trawl was and remains the primary gear employed (Wigley, 1973). The "50-70 (2-seam) trawl", so called because of head rope and foot rope length, appears to have been most commonly used, but some fishermen used semi-balloon and 4-seam designs as well (Bruce, 1971). A great variety of smaller trawls were also used aboard lobster vessels. Trawls typically were constructed of $51 \mathrm{~mm}$ stretched mesh twine in the body and $44.5 \mathrm{~mm}$ stretched mesh in the extension piece and codend. Trawls have been chain or roller rigged, depending on area and bottom fished. Trawls in current use reflect improved technology of the last two decades. There has been a trend towards use of heavier, larger roller and/or rockhopper gear. Recent years have also seen substantial improvements in electronics, which allow for much more accurate positioning and towing and thus exploitation of formerly untowable grounds. These innovations have greatly increased fishing power of the Gulf of Maine fleet.

An additional development during the 1980s involved an increased focus on finfish by-catch in the shrimp fishery and efforts to mitigate this problem. Previously, there had been little recognition of, or concern for, by-catch of finfish in the shrimp fishery. Marketable fish were kept and unmarketable fish simply discarded. Amounts discarded were often considerable (Howell and Langan, 1992). Concern over by-catch mortality in the shrimp fishery led in 1989 to a groundfish catch limit of $10 \%$ by weight of shrimp per month, or $25 \%$ by weight of shrimp per trip, in the hope of redirecting effort so as to reduce discards. At the same time, gear research was initiated to reduce by-catch. Initially, trials focused on "separator" trawls which employed various sloping panels of mesh inserted in the net to divert fish too large to pass through the mesh to another, large mesh, cod end or an escape hole. While it proved possible to achieve a good separation of shrimp and finfish, rigging was difficult and fouling often distorted the panels, rendering them ineffective. Large mesh panels behind the footrope and escape holes in the extension were also tested, each designed to take advantage of behavioral differences between shrimp and fish. Use of the latter modifications or an acceptable alternate separator configuration was required for at least part of the 1989-93 fishing seasons; but none of these innovations were very successful and discard remained substantial (Clark and Power, MS 1991).

In late-1991 and early-1992, a finfish excluder device made of a hard panel of parallel bars mounted at an angle in the extension was successfully tested. This device (the so-called "Nordmore Grate", developed by a fisherman in the Nordmore area of 
Norway), eclipsed all other gear configurations in reducing finfish by-catch. In the above trials, grates with either $19 \mathrm{~mm}$ or $25 \mathrm{~mm}$ bar spacing released over $95 \%$ by weight of fish and retained over $95 \%$ of the shrimp (Kenney et al., 1992). Many trials showed $>100 \%$ retention of shrimp with the grate compared to the no-grate control.

Shrimp trawl gear can only be used in the Exclusive Economic Zone (EEZ) portion of the Gulf of Maine with the granting of an exemption to the minimum mesh size for groundfish. The New England Fisheries Management Council, as the responsible agency for management of groundfish stocks in the EEZ, quickly indicated that it would consider revoking the exempted fishery status of the shrimp fishery if this device were not employed. Members of the Northern Shrimp Section of ASMFC, many of them the same individuals managing groundfish, continued this proactive stance by implementing regulations requiring use of the Nordmore grate with 1 inch bar spacing in the shrimp fishery effective 1 April 1992. In 1994, the shrimp fishery was decreed to be a zero by-catch fishery, with no allowable landings of finfish. Some relaxation of this rule occurred in 1997, when landings of $90 \mathrm{~kg}$ of whiting per trip as by-catch were allowed.

Although introduction of the Nordmore Grate appears to have been a great success, there are still problems with passage of small juvenile finfish, notably small whiting and flatfish, through the bars of the grate. Research continues on modifications for reducing by-catch of small finfish and small shrimp, e.g. by utilizing such devices as a second grate and/or square mesh.

A small pot fishery began in Maine in the 1970s with the advent of wire traps and gained in popularity rapidly, but declined when the fishery collapsed in the mid-1970s. This fishery has persisted in mid-coast Maine, primarily due to bottom topography which provides favorable shrimp habitat yet is too rough or restricted for trawling operations. Gear conflict occurs in more open areas, but overall, bottom conditions in this region are sufficient for economic survival of the trappers. Attempts to initiate trapping in other areas of the coast have failed due to conflicts with trawl gear. The trapped product is of good quality, as the traps only target the female shrimp once they have migrated inshore. Also, these shrimp traps, which are modified lobster traps with restricted V-trough entrances, take very few finfish. The trap fishery has landed as much as $8 \%$ of the Maine annual total, but the long-term average has been around 5\%.

\section{Trends in Abundance and Mortality}

As stated above, the existence of harvestable concentrations of northern shrimp in the western Gulf of Maine has been known since the late-1800s, but there was little or no exploitation of the resource until 1938 and demand did not increase significantly until the mid-1940s. By 1944, however, interest in the resource had developed to the level at which supply became limiting (Scattergood, 1952). Landings began to decline shortly thereafter, reaching zero from 1954 to 1957, in spite of strong demand and repeated efforts to locate harvestable quantities (Wigley, 1973; Apollonio et al., 1986). Exploratory cruises by the Bureau of Commercial Fisheries in 1954-55 (U.S. Department of Interior 1954, 1955) were also unsuccessful in locating commercial concentrations in formerly productive areas.

The fishery resumed in 1958, and landings and abundance increased steadily during the 1960s. Prior to 1968 , abundance trends were inferred primarily from commercial landings and CPUE trends. Commercial CPUE indices increased steadily to peak levels in the late-1960s in spite of rapidly increasing landings and effort, indicating pronounced increases in abundance during these years (Wigley, 1973; Clark, MS 1982). Landings and CPUE peaked from 1969 to 1972 and then declined precipitously into the late1970 s, when the fishery was closed.

Relative abundance and biomass indices derived from State of Maine, NEFSC and State-Federal surveys are given in Table 3 and Fig. 11. Maine and NEFSC indices declined by over $90 \%$ from 1968 to 1977, reflecting the resource collapse of the 1970s. The recruitment failure of this stock was very rapid. Indices declined to the lowest levels observed in 197778 (Fig. 11). Subsequently, Maine indices continued to fluctuate about a low level, while NEFSC indices increased into the $1980 \mathrm{~s}$ with improving recruitment. The peaks in 1986, 1990 and 1994-95 in the StateFederal and NEFSC autumn survey indices reflect recruitment of the strong 1982, 1987, and 1992 yearclasses, clearly the strongest since the resource collapse of the 1970s (Fig. 12). The peak in the NEFSC autumn survey index in 1981 (Fig. 11) reflects at least in part high catches of age 2 shrimp from the 1979 year-class, but this trend was not sustained in subsequent survey cruises. A general decline occurred for both the NEFSC autumn and State-Federal summer 
TABLE 3. Indices of abundance and biomass for Gulf of Maine northern shrimp developed from State of Maine, State-Federal and Northeast Fisheries Science Center research vessel surveys.

\begin{tabular}{|c|c|c|c|c|c|c|c|c|}
\hline \multirow[b]{3}{*}{ Year } & \multirow{2}{*}{\multicolumn{2}{|c|}{ Maine Summer ${ }^{1}$}} & \multirow{2}{*}{\multicolumn{2}{|c|}{ State-Federal ${ }^{2}$}} & \multicolumn{4}{|c|}{$\mathrm{NEFSC}^{2}$} \\
\hline & & & & & Spri & & Autu & \\
\hline & Numbers & Weight (kg) & Numbers & Weight (kg) & Numbers $^{3}$ & Weight (kg) & Numbers $^{3}$ & Weight $(\mathrm{kg})$ \\
\hline 1968 & 8107.6 & 45.8 & & & & 10.57 & & 3.16 \\
\hline 1969 & 5920.4 & 31.2 & & & & 4.46 & & 2.69 \\
\hline 1970 & 8322.6 & 40.8 & & & & 2.09 & & 3.66 \\
\hline 1971 & 1924.0 & 9.4 & & & & 1.86 & & 2.95 \\
\hline 1972 & 1131.2 & 7.0 & & & & 1.44 & & 3.33 \\
\hline 1973 & 2278.2 & 7.8 & & & & 1.31 & & 1.89 \\
\hline 1974 & 1066.5 & 4.9 & & & & 2.16 & & 0.75 \\
\hline 1975 & 1312.3 & 6.7 & & & & 5.40 & & 0.93 \\
\hline 1976 & 1529.3 & 4.8 & & & & 0.67 & & 0.58 \\
\hline 1977 & 368.7 & 1.6 & & & 150.7 & 0.90 & 18.5 & 0.15 \\
\hline 1978 & 540.3 & 3.2 & & & 42.7 & 0.27 & 47.6 & 0.41 \\
\hline 1979 & 645.4 & 4.4 & & & 230.3 & 1.00 & 76.3 & 0.51 \\
\hline 1980 & 492.1 & 2.7 & & & 177.1 & 0.82 & 42.1 & 0.53 \\
\hline 1981 & 483.0 & 3.0 & & & 363.9 & 2.61 & 177.8 & 1.48 \\
\hline 1982 & 392.3 & 2.0 & & & 152.2 & 1.10 & 36.9 & 0.30 \\
\hline 1983 & 945.2 & 4.2 & & & 297.7 & 1.28 & 138.5 & 0.78 \\
\hline 1984 & & & 3009.5 & 22.63 & 343.2 & 1.93 & 217.5 & 1.89 \\
\hline 1985 & & & 3532.1 & 29.39 & 81.8 & 0.70 & 176.4 & 1.60 \\
\hline 1986 & & & 3327.2 & 29.69 & 67.9 & 0.65 & 252.6 & 2.46 \\
\hline 1987 & & & 2419.4 & 21.01 & 171.7 & 1.38 & 149.5 & 1.65 \\
\hline 1988 & & & 4309.7 & 26.55 & 175.1 & 1.09 & 195.9 & 1.18 \\
\hline 1989 & & & 3579.8 & 27.32 & 205.7 & 1.41 & 229.8 & 1.81 \\
\hline 1990 & & & 3020.7 & 29.38 & 144.5 & 1.27 & 184.9 & 2.04 \\
\hline 1991 & & & 1992.1 & 18.16 & 132.2 & 0.92 & 103.2 & 0.94 \\
\hline 1992 & & & 1503.0 & 12.90 & 133.9 & 0.76 & 57.3 & 0.60 \\
\hline 1993 & & & 3569.0 & 17.87 & 141.4 & 0.65 & 362.3 & 1.83 \\
\hline 1994 & & & 3435.4 & 21.06 & 327.8 & 1.73 & 330.9 & 2.27 \\
\hline 1995 & & & 2855.6 & 21.10 & 230.0 & 1.08 & 178.3 & 1.83 \\
\hline 1996 & & & 2650.7 & 20.20 & 182.1 & 1.25 & 115.9 & 1.13 \\
\hline 1997 & & & 3160.6 & 19.82 & 207.1 & 1.21 & 180.9 & 1.35 \\
\hline 1998 & & & 2319.1 & 15.10 & 543.3 & 2.75 & 323.9 & 2.24 \\
\hline
\end{tabular}

1 Mean catch per tow at fixed stations.

2 Stratified mean catch per tow (State-Federal indices based on catches in Strata 1,3, and 5-8; NEFSC Indices based on catches in strata 24, 26-28 and 37-40).

3 Detailed sampling for numbers at length not conducted prior to 1977 .

survey biomass indices after 1994, although the autumn index increased sharply in 1998 (Fig. 11).

Index Level Assessments. This stock has been assessed annually since 1974. Initial assessments were based on State of Maine and NEFSC survey data; commercial landings, dockside interviews and biological sampling from Maine and NMFS port sampling programs, and biological parameter estimates and yield modeling (Rinaldo, 1973). Collectively these data were used in a series of assessments to generate indices of abundance and estimates of instantaneous total mortality $(Z)$ from catch-curve analysis of Maine survey data, from which estimates of instantaneous fishing mortality $(F)$ were obtained by subtracting $M$. Exploitation rates were then obtained from corresponding estimates of $F$ and $Z$ and related to catch to obtain estimates of stock size. These assessments, although not of a rigorous quantitative nature, were adequate to document the decline and collapse of the fishery in the mid- to late1970s (Anthony and Clark, 1978; Clark and Anthony, 1981; Clark, MS 1982).

These assessments documented a sharp increase in exploitation during the early- to mid-1970s with 


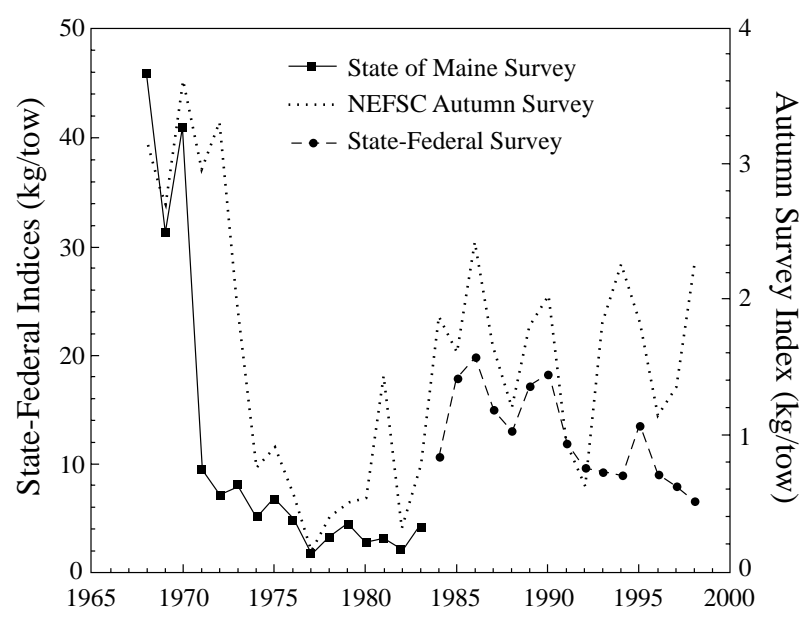

Fig. 11. Biomass indices (kg per tow) for Gulf of Maine northern shrimp derived from State of Maine, Northeast Fisheries Science Center (NEFSC) autumn, and State-Federal summer surveys, 196898. (State of Maine index, mean catch per tow at fixed stations; NEFSC index, stratified mean catchper-tow for NEFSC strata 24, 26-28, and 37-40; State-Federal index, stratified geometric mean catchper-tow, State-Federal survey strata 1, 3 and 5-8.

concomitant declines in stock biomass. Fishing mortality averaged 0.7 from 1968 to 1970 and then increased to over 1.8 during 1971-72; the 1973-77 average was 1.5. At the same time, stock biomass and recruitment declined precipitously (Fig. 13). Trends in stock size as calculated above agree well with trends in fishery-independent biomass indices (Fig. 11).

Annual assessments from 1983 to 1995 documented recruitment of the strong 1982, 1987 and 1992 year-classes and generally moderate levels of $F$ and exploitation rates as determined from the State-Federal survey. Estimates of $Z$ from catch-curve analysis of State-Federal survey data averaged 0.5 for $1984-90$ and then increased to an average of 0.9 for 1991-92 as abundance declined with passage of the 1987 yearclass through the fishery and poorer recruitment from subsequent year-classes. Estimates then declined to 0.7 and 0.6 in 1993 and 1994, respectively (NSTC, MS 1994). Under the above assumption of $M=0.25$ this implies that $F$ and exploitation rates were for the most part within acceptable limits during the 1980s and at or below levels shown to be sustainable for other stocks, e.g. in Canada (Mohn et al., 1992). The primary area of concern documented in the latter assessment was an observed high level of mortality on age 2 shrimp (from the 1992 year-class) which was expected to significantly reduce its potential yield and contribution to spawning stock biomass.

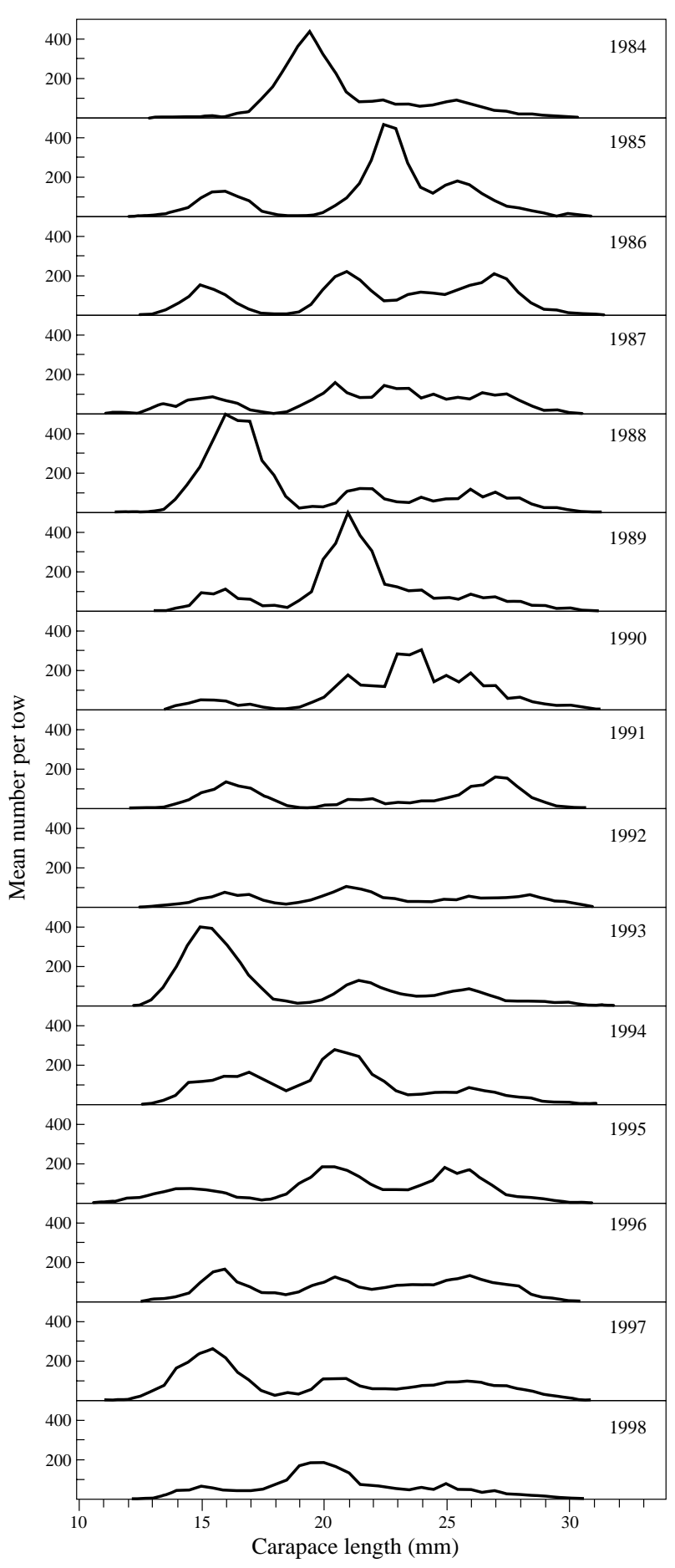

Fig. 12. Stratified mean numbers-per-tow at length for Gulf of Maine northern shrimp derived from StateFederal summer survey data, 1984-98.

Analytical Assessments. Some length-based analyses have been performed for this stock. Terceiro and Idoine (1990) tested the efficiency of Shepherd's length composition analysis (SRLCA) technique in 


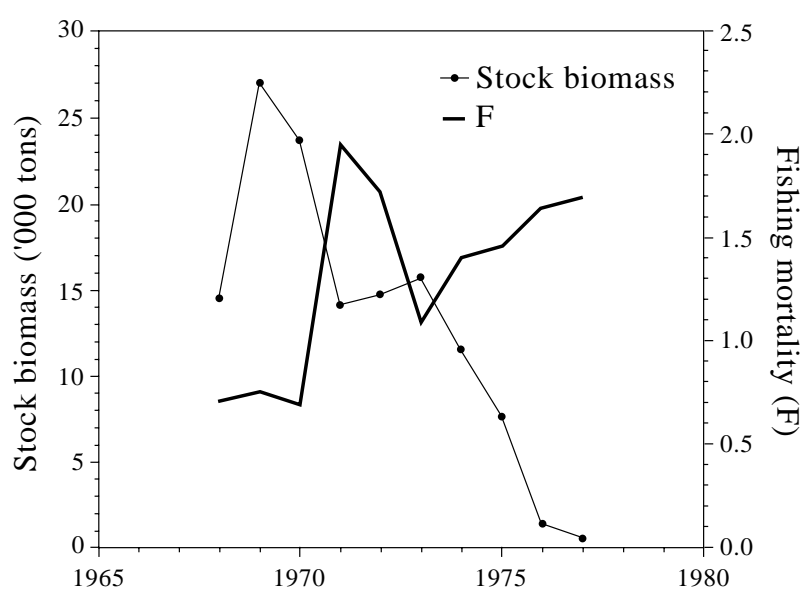

Fig. 13. Estimates of stock size and instantaneous fishing mortality $(F)$ for Gulf of Maine northern shrimp, 1968-77, derived from index-based assessments.

interpreting population age structure, using StateFederal survey data for 1984-88; Fournier et al. (1991) performed similar evaluations for 1984-89 data sets using the MULTIFAN maximum likelihood procedure. Both methods provide estimates of numbers at age by year which, in standardized surveys, can be used to generate estimates of total mortality $(Z)$. Resulting estimates of $Z$ agreed well with those derived from catch curve analysis based on visual inspection of modal groups (Fournier et al., 1991).

In 1996, the NSTC began work on an analytical stock assessment for Gulf of Maine shrimp. This assessment was a product of the Northeast Regional Stock Assessment Workshop (SAW) in the summer of 1997 (Cadrin et al., MS 1998). Analyses were subsequently updated with 1997 and 1998 fishery and survey data, which provided the basis for management advice for the 1998 and 1999 fishing seasons, respectively. Technical details on assessment methodology and results of the 1997 assessment are given by Cadrin et al. (1999). A general description and results from the 1999 assessment are reported below.

Catch-Survey Model. A Catch-Survey model (CS, Collie and Sissenwine, 1983; Conser and Idoine, MS 1992) was applied to the Gulf of Maine northern shrimp fishery in which the basic model assumes that fully-recruited abundance at the end of the annual fishing season or fishing year $\left(N_{t+1}\right)$ are the survivors from fully-recruited abundance at the beginning of the year $\left(N_{t}\right)$, plus recruitment $\left(R_{t}\right)$, minus catch (in numbers, $\left.C_{t}\right)$, all reduced by one year of natural mortality ( $e^{-M}$; assuming $\left.M=0.25\right)$ :

$$
N_{t+1}=\left(N_{t}+R_{t}-C_{t}\right) e^{-M}
$$

Catch was assumed to be taken six months from the time of the State-Federal survey (i.e., survey in August and catch in February), which was based on the time of $50 \%$ cumulative seasonal catch for $1985-$ 97:

$$
N_{t+1}=\left[\left(N_{t}+R_{t}\right) e^{-0.5 M}-C_{t}\right] e^{-0.5 M}
$$

so that recruited northern shrimp $\left(N_{t}+R_{t}\right)$ experience a half-year of natural mortality $\left(e^{-0.5 M}\right)$, catch is removed, then the survivors from the fishery $\left[\left(N_{t}+\right.\right.$ $\left.R_{t}\right) e^{-0.5 M}-C_{t}$ ] experience another half-year of natural mortality. In the model, the fishing year extends from 1 August to 31 July of the year following.

Abundance of recruits and fully-recruited shrimp were related to State-Federal survey indices of relative abundance (1984-98) and were estimated by nonlinear least squares of $\log$ survey measurement errors. Variability of estimates was assessed using conditional bootstrap analysis (Efron, 1979). One thousand bootstrapped estimates of abundance were derived by randomly resampling log errors. The initial application of the $\mathrm{C}-\mathrm{S}$ model exhibited substantial retrospective differences (i.e. changes in historical estimates when a new season of data are included in the analysis). Retrospective analysis was updated by sequentially truncating the last year of catch and survey data from the analysis and re-estimating the parameters according to Sinclair et al. (MS 1990).

The C-S model fit the survey data relatively well. Coefficients of variation (CV) for abundance estimates ranged from $18 \%$ to $25 \%$, and survey catchability was relatively well estimated $(\mathrm{CV}=18 \%)$. Recruitment estimates averaged 0.8 billion from 1984 to 1998, peaked at 1.3 billion in 1989 , but then decreased to 0.4 billion in 1998, the lowest in the time series (Table 4). Fully-recruited abundance estimates averaged 1.0 billion over the $\mathrm{C}-\mathrm{S}$ time series, peaked at 1.5 billion in 1990, and then decreased to 0.4 billion in 1998, also the lowest in the time series (Table 4). Annual estimates of $F$ averaged 0.34 from the 1985 to 1995 fishing years, increased to 0.85 during the 1997 fishing year and decreased to 0.57 during the 1998 fishing year. Estimates of total (exploitable) biomass averaged 14900 tons (12 500 tons) from 1984 to 1998 , peaked at over 22000 tons (19000 tons) in 1986 and 1990, but decreased to 6200 tons (5 000 tons) in 1998 (Table 4, Fig. 14). Total mortality estimates were within the range of length-based analyses for the same period (Terceiro and Idoine, 1990; Fournier et al., 
1991). Retrospective changes experienced initially were not apparent in subsequent years (i.e. differences between the present solution and the 1997 assessment were negligible).

Surplus Production Model. An alternative method of estimating stock size and $F$ was employed for comparison to results from $\mathrm{C}-\mathrm{S}$ analysis. A nonequilibrium surplus production model (ASPIC; Prager, 1994; 1995) was fit to total catch and survey biomass indices from the 1968 to 1997 fishing seasons. The model assumes logistic population growth, in which the change in stock biomass over time $\left(d B_{t} / d t\right)$ is a quadratic function of biomass $(B)$ and yield $(Y$, in units of biomass):

$$
d B_{t} / d t=r B_{t}-(r / K) B_{t}^{2}-Y_{\mathrm{t}}
$$

where $r$ is the instantaneous annual growth rate, and $K$ is the carrying capacity. Relative biomass indices from the State of Maine survey, the NEFSC autumn bottom trawl survey, and the State-Federal survey were used to calibrate the predicted biomass trajectory. Biomass in the first year of the analysis $(1968)$ and the production parameters $(r$ and $K$ ) were estimated by nonlinear least squares of log survey measurement errors. Note that no assumption about $M$ is needed for the surplus production analysis. Log survey measurement errors were randomly resampled 1000 times for bootstrap estimates of precision.
Survey indices of stock biomass were moderately correlated $(r=0.74$ between the State of Maine and autumn bottom trawl surveys, and $r=0.51$ between the autumn bottom trawl and State-Federal surveys). The majority of variance in the autumn bottom trawl and State of Maine surveys was explained by the model $\left(R^{2}=0.65\right.$ and 0.67 , respectively), but less variation in the State-Federal survey was resolved $\left(R^{2}=0.16\right)$. The production model could not account for the distinct recent recruitment events, which were apparent from the State-Federal survey and commercial sampling data, because the production model implicitly assumes a generalized level of recruitment as a function of stock biomass, and survey indices of recruitment are not considered in the model. The result of ignoring recruitment signals is that patterns of biomass from the State-Federal survey were interpreted as observation error and little variance was explained. Therefore, biomass estimates in any one year should be suspect. However, estimates of $F$ and stock size from the biomass dynamics model generally confirm the pattern and magnitude of estimates from the $\mathrm{C}-\mathrm{S}$ model (Fig. 15). The production model provides a longer perspective on stock status than the $\mathrm{C}-\mathrm{S}$ model. Biomass estimates exceeded 40000 tons in the late-1960s, decreased steadily to less than 5000 tons in the late-1970s, increased to a stable average of 15000 tons for 1984-96, and then decreased to 5000 tons in 1999, the lowest estimate since 1979

TABLE 4. Summary of results from Catch-Survey analysis of the Gulf of Maine northern shrimp fishery (abundance in millions, biomass in thousands of tons).

\begin{tabular}{lcccccc}
\hline \hline $\begin{array}{l}\text { Survey } \\
\text { Year }\end{array}$ & $\begin{array}{c}\text { Recruit } \\
\text { Abundance }\end{array}$ & $\begin{array}{c}\text { Fully-recruited } \\
\text { Abundance }\end{array}$ & $\begin{array}{c}\text { Total } \\
\text { Biomass }\end{array}$ & $\begin{array}{c}\text { Exploitable } \\
\text { Biomass }\end{array}$ & $\begin{array}{c}\text { Fishing } \\
\text { Year }\end{array}$ & $\begin{array}{c}\text { Fishing } \\
\text { Mortality }\end{array}$ \\
\hline 1984 & 988 & 949 & 14.075 & 11.241 & 1985 & 0.10 \\
1985 & 1177 & 1369 & 21.694 & 17.737 & 1986 & 0.29 \\
1986 & 973 & 1481 & 22.245 & 19.115 & 1987 & 0.43 \\
1987 & 698 & 1242 & 17.791 & 15.523 & 1988 & 0.46 \\
1988 & 1186 & 958 & 14.018 & 11.425 & 1989 & 0.18 \\
1989 & 1317 & 1398 & 20.626 & 16.709 & 1990 & 0.33 \\
1990 & 832 & 1522 & 22.234 & 19.161 & 1991 & 0.44 \\
1991 & 610 & 1180 & 17.004 & 15.170 & 1992 & 0.46 \\
1992 & 513 & 884 & 12.431 & 10.920 & 1993 & 0.42 \\
1993 & 713 & 715 & 9.223 & 7.738 & 1994 & 0.32 \\
1994 & 977 & 811 & 12.405 & 9.857 & 1995 & 0.33 \\
1995 & 884 & 1004 & 15.532 & 12.851 & 1996 & 0.66 \\
1996 & 533 & 763 & 10.996 & 9.426 & 1997 & 0.85 \\
1997 & 516 & 430 & 6.804 & 5.557 & 1998 & 0.57 \\
1998 & 440 & 418 & 6.208 & 5.019 & & 0.42 \\
Average & 824 & 1008 & 14.886 & 12.497 & & \\
\hline
\end{tabular}



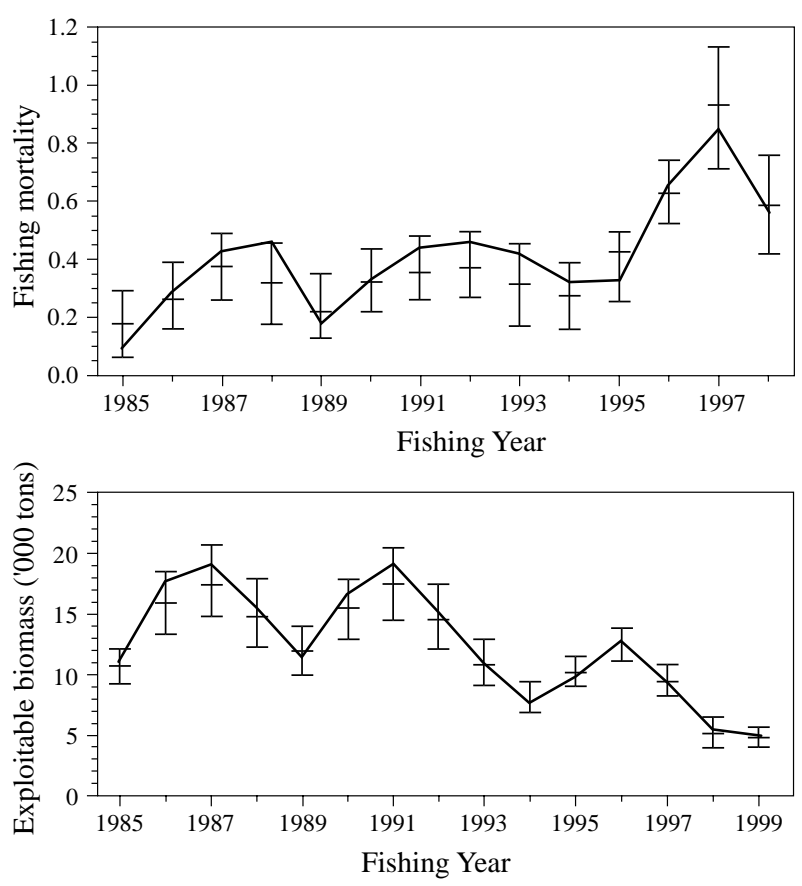

Fig. 14. Estimates of instantaneous fishing mortality $(F)$ and exploitable biomass for Gulf of Maine northern shrimp derived from Catch-Survey analysis. Leastsquares estimates are plotted together with bootstrapped means and $80 \%$ confidence limits.

(Fig. 15). Bootstrap results suggest that model parameters were estimated with moderate precision (relative interquartile ranges were $15 \%-25 \%$ ).

Yield- and Eggs-per-Recruit Model. Yield-perrecruit (Thompson and Bell, 1934) and percent maximum spawning potential (Gabriel et al., 1989; Goodyear, 1993) were estimated to develop biological reference points for the Gulf of Maine fishery (Fig. 16). For these dynamic pool methods, "recruit" refers to recruitment to the population (a newly hatched individual), whereas it refers to recruitment to the fishery in the C-S model. Maximum yield-per-recruit was $4.2 \mathrm{~g}$ at $F=0.77\left(F_{\max }\right)$; the increase in yield per unit $F$ decreased to one-tenth the initial increase at $F$ $=0.46\left(F_{0.1}\right)$. Maximum spawning potential (i.e. with no $F$ ) was 2400 eggs-per-recruit. Spawning potential was reduced by half at $F=0.25\left(F_{50 \%}\right)$ and to $20 \%$ at $F=0.63\left(F_{20 \%}\right)$.

Eggs-per-recruit reference points are appropriate management targets for Gulf of Maine northern shrimp, because there appears to be a strong spawnerrecruit relationship, and low levels of spawning potential increase the risk of poor recruitment. Reproductive success for Gulf of Maine northern
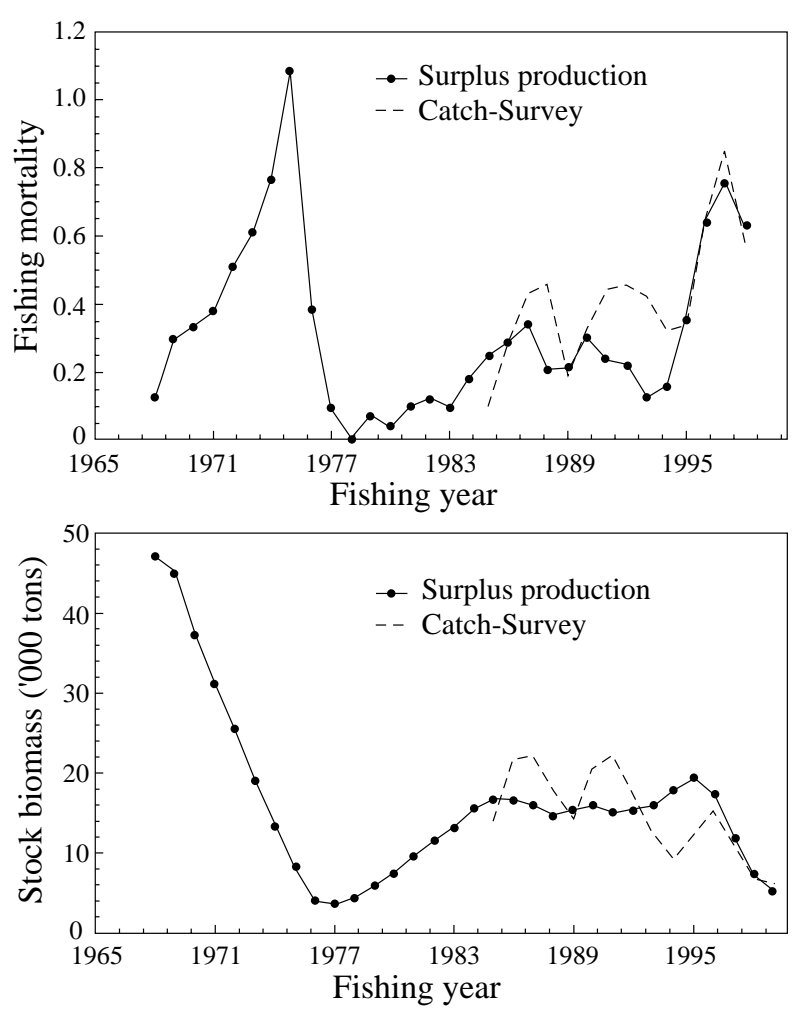

Fig. 15. Estimates of instantaneous fishing mortality $(F)$ and stock biomass for Gulf of Maine northern shrimp derived from Catch-Survey and surplus-production modeling.

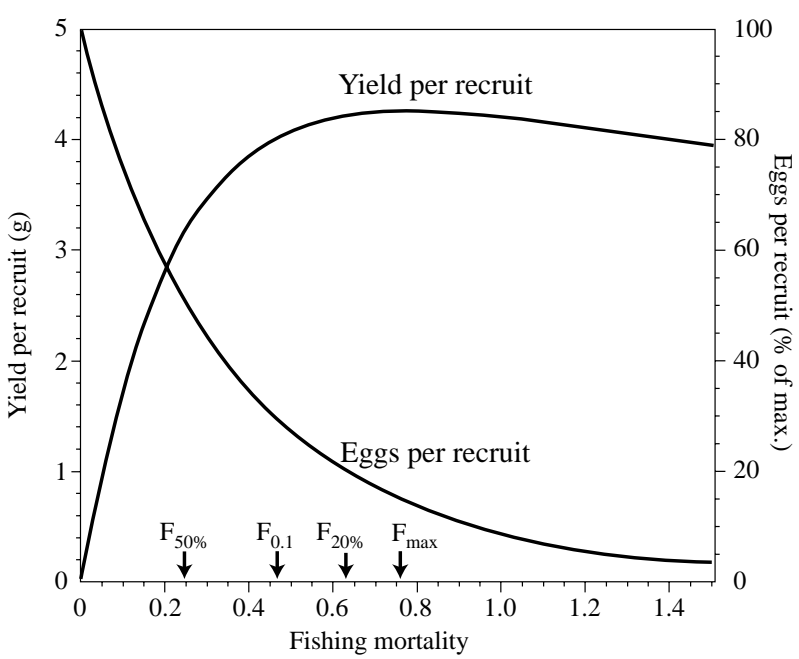

Fig. 16. Results of yield and egg production-per-recruit modeling for Gulf of Maine northern shrimp.

shrimp is a function of population fecundity and spring seawater temperature (Richards et al., MS 1996), and landings are correlated to lagged population fecundity (Stickney, MS 1980; Apollonio et al., 1986; Richards et al., MS 1996). 
Environmental Influences. Several studies have documented a relationship between abundance and temperature trends. Dow $(1963,1964,1966)$ observed a negative relationship between sea-surface temperatures measured at Boothbay Harbor, Maine and subsequent landings. Poor production years were found to be associated with consistently high, or fluctuating, monthly temperatures, while high production years were associated with years in which monthly fluctuations were minimal and temperatures were moderately low (Dow, 1964). Dow (1977a, 1997b) later found a significant negative correlation between sea-surface temperature trends and landings four years later (Fig. 17). The most obvious features evidenced here are (1) the unusually warm temperatures of the early-1950s, which were associated with complete failure of the fishery from 1954 to 1957, and (2) the unusually cool temperatures of the mid-1960s, which were associated with record landings from 1969 to 1972 . (Note that a 4-year lag has been commonly used for temperature data in such plots, under the assumption that temperature effects would be most significant in the first year of life). Time series of temperature anomalies for spring surface and autumn bottom temperatures from NEFSC surveys since 1968 are given in Fig. 18.

There have been a number of intensive investigations of the biological effects of temperature on northern shrimp in the Gulf of Maine. A number of studies have considered the effects of bottom temperature. Apollonio and Dunton (1969) observed

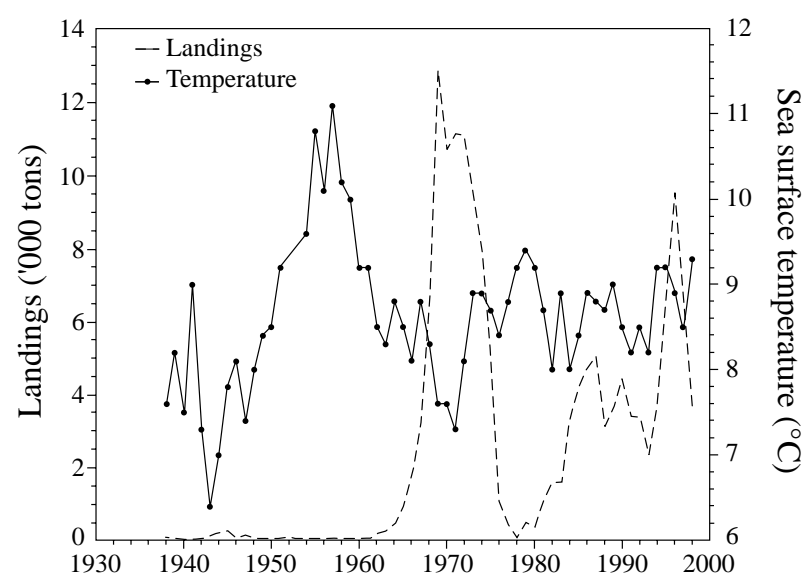

Fig. 17. Annual landings for Gulf of Maine northern shrimp plotted against mean annual sea-surface temperatures recorded at Boothbay Harbor, Maine. Temperature data were lagged forwards by a period of 4 years. that egg development was adversely affected by warmer temperatures, with the appearance of progressively larger numbers of nonviable eggs. They suggested that warm winter temperatures of the early1950 s resulted in non-viable eggs and poor subsequent recruitment. Stickney and Perkins (1977) were unable to demonstrate significant egg or larval mortality at temperatures up to $12^{\circ} \mathrm{C}$ under laboratory conditions, which would appear to rule out direct temperature induced mortality in the Gulf of Maine; but they found a marked effect of warmer temperatures on length of the incubation period. Their findings indicated that, between a "cold" winter with an average bottom temperature of $4.4^{\circ} \mathrm{C}$ and a "warm" winter with an average bottom temperature of $6.5^{\circ} \mathrm{C}$, there could be a difference of a month in the hatching date. They concluded that the effect of warmer temperatures could be indirect, e.g. early hatching before sufficient planktonic food appeared in the water column. Subsequent work on this question was inconclusive, however (Stickney and Perkins, 1979).

Another potential effect of bottom temperature involves changes in fecundity, which could be induced through direct physical effects or parasitism. With respect to the former, Apollonio et al. (1986) found a strong relationship between temperature and fecundity, i.e. high fecundities in the mid-1960s and
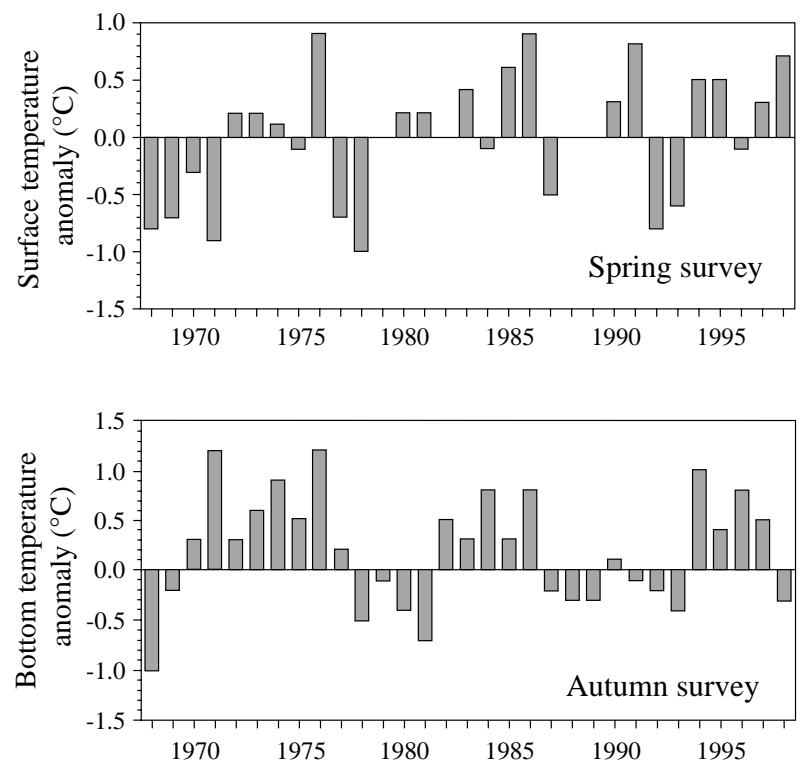

Fig. 18. Spring surface and autumn bottom temperature anomalies for the western Gulf of Maine determined from Northeast Fisheries Science Center (NEFSC) spring and autumn bottom trawl survey data, 196898 (modified from Richards et al., MS 1996). 
late-1970s corresponded with periods of low AprilJuly offshore bottom temperatures in the southwest Gulf of Maine; while low fecundities in the late-1960s and early-1970s corresponded with high offshore bottom temperatures in these locations and years. They proposed that a direct temperature influence, i.e. via stratification, and resulting changes in temperature encountered by maturing females in their vertical migrations, could be involved in some way. Further, they demonstrated a strong positive correlation between fecundity and landings four years later. The resulting inference was that temperature-induced changes in fecundity could at least partially explain historical trends in abundance. Similarly, Nunes (Apollonio et al., 1986) concluded that fecundity in the Gulf of Alaska could vary with temperature by as much as $20 \%$, based on laboratory studies. Population effects could have been at work as well, e.g. Stickney (MS 1980) found an inverse relationship between landings (as a proxy for abundance) and fecundity in the same year, suggesting density dependence.

With respect to biotic effects, egg masses in the Gulf of Maine are subject to infestation by a number of epizoic bacteria and protozoa (Apollonio et al., 1986) and by an internal parasitic dinoflagellate (Stickney, 1978). Apollonio et al. (1986) observed that internal and external parasitism were associated with warmer temperatures, e.g. little or no infestation at temperatures of $5.5^{\circ} \mathrm{C}$ or less, but considerable infestation at higher temperatures. Apollonio and Dunton (1969) observed that premature shedding of non-viable eggs accompanied development of nonviable egg masses, together with protozoan infestations. Stickney and Perkins (1979) noted higher fecundity in 1979 than during the much warmer winters of 1974 and 1975, which was associated with a decline in incidence of egg mortality from an internal parasitic dinoflagellate (Stickney, 1978). Development of this parasite is slowed at lower temperatures (Stickney, 1981).

The above research demonstrates that temperature conditions have been important in determining historical trends in abundance for northern shrimp in the Gulf of Maine; but the precise mechanisms involved remain elusive and difficult to quantify. Relative to the 1970s collapse, the picture is further complicated by increases in effort and exploitation, which coincided with increasing temperatures from the late-1960s to the mid-1970s (Anthony and Clark, 1978). A sixteen fold increase in standardized effort occurred between 1964 and 1972 (Clark, MS 1982; McInnes, 1986) while mean annual sea-surface temperatures rose from $7.3^{\circ} \mathrm{C}$ in 1967 to $9.4^{\circ} \mathrm{C}$ in 1975 (NEFSC autumn bottom temperatures in the western Gulf of Maine reached $8.7^{\circ} \mathrm{C}$ in 1976 , the highest in this time series). To examine the relative effects of temperature and exploitation more directly, Richards et al. (MS 1996) developed reproductive capacity and recruitment indices from survey time series and related these to seasonal surface and bottom temperature anomalies. They expressed reproductive capacity in the form of population fecundity indices, developed by applying a size fecundity relationship to mean numbers at length per tow; recruitment indices were expressed as mean numbers of age 1 individuals per tow. They then fit a generalized stock- recruitment model to these data sets to examine the relative influence of temperature and reproductive capacity using several biologically feasible lags. No effects were found relating to bottom temperature anomalies; however, reproductive capacity and spring surface temperature (year of hatching) were significant, with recruitment being inversely related to spring surface temperature (Richards et al., MS 1996). This analysis provides a promising lead for further investigations of stock-recruitment relationships under different temperature regimes.

\section{Management}

The foundation for management of the Gulf of Maine northern shrimp stock was provided by congressional approval of a compact "relating to the better utilization of the fisheries... of the Atlantic seaboard and creating the Atlantic States Marine Fisheries Commission" (PL 539, 77 $7^{\text {th }}$ Congress, as amended by PL $721,81^{\text {st }}$ Congress, approved 19 August 1950). Amendment 1 to the compact allows consenting States to designate the Commission as a joint regulatory agency "for the regulation of the fishing operations of the citizens and vessels of such designating States with respect to specific fisheries in which such States have a common interest" (McInnes, 1986). Under this arrangement representatives of the participating States constitute a separate Section for management of the fishery so designated. In this case the ASMFC Northern Shrimp Section (hereafter referred to as the Section) consisting of representatives from Maine, New Hampshire and Massachusetts, is and has been responsible for management of the fishery based on input from the Northern Shrimp Scientific (now Technical) Committee (hereafter referred to as the Committee), and industry. This arrangement was unique for many years and is considered one of the few instances of continuous interstate cooperation in the history of USA fishery management (Rieser and Ziegler, 1982). Table 
5 summarizes regulations adopted for this fishery under the auspices of the Commission.

Management of the fishery had its origins in 1972, when industry concerns over declining abundance and product quality led to meetings between state representatives and NMFS to discuss options for cooperative management. A memorandum of understanding was signed in April 1973, in which the three states and NMFS agreed to cooperate in management of the resource through the State-Federal Fishery Management Program (with ASMFC as the regulatory authority). The Committee was responsible for providing assessments and management advice to the Section. Initial interest centered around curtailing harvest of small, non-marketable shrimp, which led to a cooperative gear evaluation study beginning in July of 1973 (NSSC, 1979). By October of that year, each state had adopted an interim codend mesh size regulation of $38 \mathrm{~mm}$ or 1.5 inches (stretched mesh). Unfortunately, this mesh size, coupled with a $3 \mathrm{~mm}$ tolerance allowance and inadequate enforcement, resulted in only minimal constraints upon industry. Results of the gear evaluation study, which became available in early-1974, indicated that a uniform stretched mesh size of $44 \mathrm{~mm}$ (1.75 inches) in the body and codend of the trawl would be appropriate for the Gulf of Maine northern shrimp stock. This mesh size was shown to retain most mature females while allowing escapement of over $75 \%$ of the smaller males, thereby increasing yield per recruit considerably. Unfortunately, implementation of a uniform mesh size regulation was repeatedly delayed because of industry opposition. The mesh size regulation finally became effective in September 1975, but was not formally enforced in all areas until the following year. Enforcement continued to remain an issue for several years thereafter. Failure to implement and enforce this regulation in a more timely fashion was unfortunate because of the intensive offshore summer fishery in the early-1970s.

The Committee initiated stock assessment work in December of 1974. This assessment indicated that $F$ had more than doubled between 1968 and 1973, with exploitation rates of over $70 \%$; and stock size and recruitment were declining sharply (Fig. 13). The Committee recommended limiting 1975 catches to 4200 tons to stabilize the resource (which equated to a recommendation for a 7-month closed season, as the Committee was asked to structure its advice in the form of seasonal limitations rather than quotas). The actual measure adopted was for a closure from 5 July through 27 September, implemented through
ASMFC. Implementation of the uniform mesh regulation was relaxed until after the closed season. Actual landings for 1975 totaled 5300 tons.

The Committee's November 1975 assessment indicated continued high mortality and exploitation rates and concomitant declines in recruitment and stock size. By this time the resource was becoming almost wholly dependent upon incoming recruitment. To halt further declines, the Committee recommended that landings should be held to 2300 tons, and that fishing be permitted only from 15 March to 31 July 1976 to enhance recruitment prospects through protection of ovigerous females. Counter-arguments were that (1) since previous studies had shown that temperature governed trends in abundance, seasonal closures (or perhaps any form of effort controls) would prove ineffective; and (2) a winter season was necessary on economic grounds. Environment proved to be a major issue in this and subsequent meetings, as temperatures had warmed considerably during the early-1970s (Fig. 17 and 18). As a result, the Section opted for an open season from 1 January to 15 April 15,1976 , followed by indefinite closure. Landings for 1976 totaled approximately 1000 tons.

In autumn 1976, the Committee presented assessment results which indicated continued high levels of $F$ and reductions in stock size to under 5000 tons. By this time, commercial and research vessel survey indices were at or near record lows (Fig. 11). To enhance future recovery prospects the Committee recommended continuation of the indefinite closure through 1977. This was met with vigorous opposition by industry, with similar arguments to those voiced in previous meetings. Temperature influences were a major concern, although the Committee presented evidence that fishing effort could have had an even stronger impact upon resource trends during the 196875 time frame. Considerable pressure was also exerted for an open season on economic grounds, although an economic analysis was also available which indicated unfavorable economic prospects (Dunham and Mueller, 1976). As a result, the Section opted for an open season extending from 1 January-15 May 1977 with a quota limitation of 1600 tons, followed by indefinite closure. Only 400 tons were landed in the ensuing season.

The Committee's October 1977 assessment showed that in spite of low 1977 landings, resource conditions had continued to deteriorate, and projections indicated a 1978 stock size in the order of 1000 tons. No age 1 shrimp were observed in either 
TABLE 5. Recommendations made and actions taken for management of the Gulf of Maine northern shrimp resource, 197398 (Modified from Clark, MS 1982 and McInnes, 1986).

\begin{tabular}{|c|c|c|}
\hline Year/Season & Recommendations & Actions Taken \\
\hline 1973 & - $\quad$ Adoption of mesh regulations & $\begin{array}{l}\text { - Provisions for gear evaluation studies } \\
\text { Adoption of interim minimum mesh size regulation } \\
\text { requiring use of trawls with stretched mesh sizes of } \\
\text { not less than }(\mathrm{nlt}) 44.5 \mathrm{~mm}(1.75 \mathrm{in}) \text { in the body and } \\
38 \mathrm{~mm}(1.50 \mathrm{in}) \text { in the codend }\end{array}$ \\
\hline 1974 & $\begin{array}{l}\text { - Adoption of uniform minimum mesh size } \\
\text { regulation requiring use of trawls with } \\
\text { stretched mesh sizes of nlt } 44.5 \mathrm{~mm}(1.75 \mathrm{in}) \\
\text { in the body and codend }\end{array}$ & \\
\hline 1975 & $\begin{array}{l}\text { - Adoption of uniform minimum mesh size } \\
\text { regulation } \\
\text { Restriction of } 1975 \text { harvest to } 4200 \text { tons } \\
\text { (9.2 million lbs) by a seasonal closure of } \\
7 \text { months }\end{array}$ & $\begin{array}{l}\text { - Establishment of regulations requiring use of trawls } \\
\text { with a stretched mesh size of nlt } 44.5 \mathrm{~mm}(1.75 \mathrm{in}) \text { in } \\
\text { the body and codend. Tolerance } 3 \mathrm{~mm}(0.13 \mathrm{in}) \text { and } 6 \\
\mathrm{~mm}(0.25 \mathrm{in}) \text { allowed in body and codend, } \\
\text { respectively (effective September } 1975) \\
\text { - Closure of the fishery from } 5 \text { July-27 September } 1975\end{array}$ \\
\hline 1976 & $\begin{array}{l}\text { - Restriction of } 1976 \text { harvest to } 2300 \text { tons } \\
\text { (5 million lbs) to be taken between } 15 \text { March } \\
\text { and } 31 \text { July. } \\
\text { - Continuation of mesh regulations. }\end{array}$ & $\begin{array}{l}\text { - Open season, } 1 \text { January-15 April 1976, followed by } \\
\text { indefinite closure } \\
\text { - Continuation of mesh regulations }\end{array}$ \\
\hline 1977 & - Continuation of closure. & $\begin{array}{l}\text { - Open season, } 1 \text { January-15 May } 1977 \text {, followed by } \\
\text { indefinite closure } \\
\text { Restriction of } 1977 \text { harvest to } 1600 \text { tons }(3.5 \text { million } \\
\text { lbs) } \\
\text { - Continuation of mesh regulations }\end{array}$ \\
\hline 1978 & - Continuation of closure & - Continuation of closure \\
\hline 1979 & - Continuation of closure & $\begin{array}{l}\text { - Open season, } 15 \text { February-31 March } 1979 \\
\text { - Continuation of mesh regulations }\end{array}$ \\
\hline 1980 & $\begin{array}{l}\text { - } \quad \text { Continuation of closure } \\
\text { - } \quad \text { Continuation of mesh regulations }\end{array}$ & $\begin{array}{l}\text { - Open season, } 15 \text { February-31 May } 1980 \\
\text { - } \quad \text { Continuation of mesh regulations }\end{array}$ \\
\hline 1981 & $\begin{array}{l}\text { - Restriction of fishing season to late winter and } \\
\text { early spring (February-March) } \\
\text { - Continuation of mesh regulations }\end{array}$ & $\begin{array}{l}\text { - Open season, } 1 \text { January-15 May } 1981 \\
\text { - Continuation of mesh regulations }\end{array}$ \\
\hline 1982 & $\begin{array}{l}\text { - } \quad \text { Restriction of season to winter and early } \\
\text { spring } \\
\text { - } \quad \text { Continuation of mesh regulations }\end{array}$ & $\begin{array}{l}\text { - Open season, } 1 \text { January-15 April } 1982 \\
\text { - } \quad \text { Continuation of mesh regulations }\end{array}$ \\
\hline 1983 & $\begin{array}{l}\text { - } \quad \text { Restriction of season to winter and early } \\
\text { spring } \\
\text { - } \quad \text { Continuation of mesh regulations }\end{array}$ & $\begin{array}{l}\text { Open season, } 15 \text { December } 1982-30 \text { April } 1983 \text { with } \\
\text { a possible extension of } 15 \text { days or until count exceeds } \\
70 / \text { pound for any one trip } \\
\text { - Continuation of mesh regulations }\end{array}$ \\
\hline 1984 & $\begin{array}{l}\text { - } \quad \text { Restriction of season to winter and early } \\
\text { spring } \\
\text { - } \quad \text { Continuation of mesh regulations }\end{array}$ & $\begin{array}{l}\text { Open season, } 15 \text { December } 1983 \text { il } 1984 \text { with a } \\
\text { possible extension of } 15 \text { days or until count exceeds } \\
70 / \text { pound for any one trip } \\
\text { - Continuation of mesh regulations }\end{array}$ \\
\hline
\end{tabular}


TABLE 5. (Continued). Recommendations made and actions taken for management of the Gulf of Maine northern shrimp resource, 1973-98 (Modified from Clark, MS 1982 and McInnes, 1986).

\begin{tabular}{|c|c|c|}
\hline Year/Season & Recommendations & Actions Taken \\
\hline 1997 & $\begin{array}{l}\text { - } \quad \text { Restriction of effort in December, April and } \\
\text { May } \\
\text { - } \quad \text { Continuation of mesh regulations }\end{array}$ & $\begin{array}{l}\text { - Open season, } 1 \text { December 1996-27 May 1997, for mobile } \\
\text { and trap gear except as follows: 24-28 December; 27-31 } \\
\text { January; 17-20 February; 24-27 March; and 21-24 April. } \\
\text { Trap gear may be left untended } \\
\text { - } \quad \text { Continuation of mesh regulations } \\
\text { - Finfish excluder devices required }\end{array}$ \\
\hline 1998 & $\begin{array}{l}\text { - } \quad \text { Restriction of season to February-March } \\
\text { - } \quad \text { Continuation of mesh regulations }\end{array}$ & $\begin{array}{l}\text { Open season, } 8 \text { December 1997-22 May 1998, for mobile } \\
\text { gear; fishing prohibited all weekends except 14-15 } \\
\text { March; and also 25-31 December and 16-31 March } \\
\text { - Open season, 1 January-15 March for trap gear, fishing } \\
\text { prohibited on Sundays except } 15 \text { March } \\
\text { - Continuation of mesh regulations } \\
\text { - Finfish excluder devices required }\end{array}$ \\
\hline 1999 & $\begin{array}{l}\text { - } \quad \text { Restriction of season to } 40 \text { days } \\
\text { during February-March } \\
\text { - } \quad \text { Continuation of mesh regulations }\end{array}$ & $\begin{array}{l}\text { - Open season, } 15 \text { December 1998-25 May 1999, for } \\
\text { mobile gear; fishing prohibited on weekends, plus } \\
\text { 24-25 December; } 28 \text { December-1 January; 27-29 } \\
\text { January; 24-26 February; 17-31 March; and 29-30 April } \\
\text { - } \quad \text { Open season, 10 January-10 March for trap gear } \\
\text { - Continuation of mesh regulations } \\
\text { - } \quad \text { Finfish excluder devices required }\end{array}$ \\
\hline
\end{tabular}

the 1976 or 1977 Maine survey cruises although the 1971-75 average was 5200 shrimp per tow. On the basis of this assessment and the obvious collapse of the fishery, the Section took no further action and the fishery remained closed through 1978.

The Committee's 1978 and 1979 assessments showed little if any improvement in stock size, although a substantial reduction in mortality was evident. The Committee recommended continuation of the indefinite closure through 1979. The Section, however, opted for an open season during February and March of that year, followed by indefinite closure. Landings totaled 400 tons. In retrospect this appears to have been the best possible compromise in this situation, as it focused mortality on mature females after their eggs had hatched. For 1980 the Committee again recommended continuation of the closure to promote stock rebuilding, but the Section opted for an expanded season, from 15 February to 31 May. Landings totaled 300 tons. By autumn of 1980 , it was apparent that the stock had stabilized at a low level, and the Committee advised that while any level of exploitation entailed a risk of further declines in abundance, the potential for adverse impacts could be minimized by confining the fishery to late winter and early spring.
In 1979, the Committee prepared and submitted a draft management plan and environmental impact statement for the northern shrimp fishery, which recommended regulatory measures including mesh size limits, closed seasons, catch quotas and statistical reporting. Such regulations were to be implemented by the participating states through the Northern Shrimp Section, and ultimately by the Secretary of Commerce through the Fishery Conservation and Management Act of 1976 (NSSC, 1979). A revised Plan reflecting public comment was accepted at the November 1979 Section meeting.

In 1981, the State-Federal Fishery Management Program in the Northeast Region was restructured as the Interstate Fisheries Management Program (ISFMP) of ASMFC; and the Northern Shrimp Scientific Committee became the Northern Shrimp Technical Committee. The Section took an important step forward in 1981 by adopting a "Statement of Policy" which (1) stated its position relative to environmental issues, i.e., that despite natural fluctuations in abundance, the northern shrimp fishery is manageable; and (2) affirmed that it would provide for a continuing management program based on Technical Committee recommendations to maintain and rebuild the stock so as to "assure a viable northern 
TABLE 5. (Continued). Recommendations made and actions taken for management of the Gulf of Maine northern shrimp resource, 1973-98 (Modified from Clark, MS 1982 and McInnes, 1986).

\begin{tabular}{|c|c|c|}
\hline Year/Season & Recommendations & Actions Taken \\
\hline 1985 & $\begin{array}{l}\text { - } \quad \text { Restriction of season to winter and early } \\
\text { spring } \\
\text { - } \quad \text { Continuation of mesh regulations }\end{array}$ & $\begin{array}{l}\text { - Open season, } 1 \text { December 1984-15 May } 1985 . \\
\text { During May, count shall not exceed 70/pound } \\
\text { - Continuation of mesh regulations }\end{array}$ \\
\hline 1986 & $\begin{array}{l}\text { - Extension of season to maximum allowed } \\
\text { under policy statement } \\
\text { - Continuation of mesh regulations }\end{array}$ & $\begin{array}{l}\text { - } \quad \text { Open season, } 1 \text { December 1985-31 May } 1986 \\
\text { - } \quad \text { Continuation of mesh regulations } \\
\text { - } \quad \text { Two week emergency opening 8-21 June }\end{array}$ \\
\hline 1987 & $\begin{array}{l}\text { - Extension of season to maximum allowed } \\
\text { under policy statement } \\
\text { - Continuation of mesh regulations }\end{array}$ & $\begin{array}{l}\text { - Open season, } 1 \text { December 1986-31 May } 1987 \\
\text { - } \quad \text { Continuation of mesh regulations }\end{array}$ \\
\hline 1988 & $\begin{array}{l}\text { - } \quad \text { Restriction of season to winter and spring } \\
\text { - } \quad \text { Continuation of mesh regulations }\end{array}$ & $\begin{array}{l}\text { - Open season, } 1 \text { December 1987-31 May } 1988 \\
\text { - Continuation of mesh regulations, except } 0.25 \text { in } \\
\text { tolerance in codend eliminated }\end{array}$ \\
\hline 1989 & $\begin{array}{l}\text { Extension of season to maximum allowed } \\
\text { under policy statement } \\
\text { - Continuation of mesh regulations }\end{array}$ & $\begin{array}{l}\text { - } \quad \text { Open season, } 1 \text { December 1988-31 May } 1989 \\
\text { - } \quad \text { Continuation of mesh regulations } \\
\text { - } \quad \text { Shrimp separator trawls required in April and May }\end{array}$ \\
\hline 1990 & $\begin{array}{l}\text { Extension of season to maximum allowed } \\
\text { under policy statement } \\
\text { - Continuation of mesh regulations }\end{array}$ & $\begin{array}{l}\text { - Open season, } 1 \text { December 1989-31 May } 1990 \\
\text { - Continuation of mesh regulations } \\
\text { - Shrimp separator trawls required in December, April } \\
\text { and May }\end{array}$ \\
\hline 1991 & $\begin{array}{l}\text { Extension of season to maximum allowed } \\
\text { under policy statement } \\
\text { - Continuation of mesh regulations }\end{array}$ & $\begin{array}{l}\text { - } \quad \text { Open season, } 1 \text { December 1990-31 May } 1991 \\
\text { - } \quad \text { Continuation of mesh regulations } \\
\text { - Shrimp separator trawls required through duration of } \\
\text { season }\end{array}$ \\
\hline 1992 & $\begin{array}{l}\text { - } \quad \text { Restriction of season from January-March } \\
\text { - } \quad \text { Continuation of mesh regulations }\end{array}$ & $\begin{array}{l}\text { - } \text { Open season, 16 December 1991-15 May } 1992 \\
\text { - } \quad \text { Fishing prohibited on Sundays } \\
\text { - } \quad \text { Continuation of mesh regulations } \\
\text { - } \quad \text { Shrimp separator trawls required from } 16 \text { December } \\
\text { 1991-31 March } 1992 \\
\text { - } \quad \text { Finfish excluder devices required from } 1 \text { April-15 May }\end{array}$ \\
\hline 1993 & $\begin{array}{l}\text { - } \quad \text { Restriction of season from January-March } \\
\text { - } \quad \text { Continuation of mesh regulations }\end{array}$ & $\begin{array}{ll}\text { - } & \text { Open season, } 14 \text { December 1992-30 April } 1993 \\
\text { - } & \text { Fishing prohibited on Sundays } \\
\text { - } & \text { Continuation of mesh regulations } \\
\text { - } & \text { Finfish excluder devices and separator panels required }\end{array}$ \\
\hline 1994 & $\begin{array}{l}\text { - } \quad \text { Restriction of season from January-March } \\
\text { - } \quad \text { Continuation of mesh regulations }\end{array}$ & $\begin{array}{l}\text { - Open season, } 15 \text { December 1993-15 April } 1994 \\
\text { - } \quad \text { Continuation of mesh regulations } \\
\text { - } \quad \text { Finfish excluder devices required }\end{array}$ \\
\hline 1995 & $\begin{array}{l}\text { - } \quad \text { Restriction of season from January-March } \\
\text { - } \quad \text { Continuation of mesh regulations }\end{array}$ & $\begin{array}{ll}\text { - } & \text { Open season, } 15 \text { December 1994-15 April } 1995 \\
\text { - } & \text { Fishing prohibited on Fridays or Sundays (state choice) } \\
\text { - } & \text { Continuation of mesh regulations } \\
\text { - } & \text { Finfish excluder devices required }\end{array}$ \\
\hline 1996 & $\begin{array}{l}\text { Extension of season to maximum allowable } \\
\text { under policy statement } \\
\text { - } \quad \text { Continuation of mesh regulations }\end{array}$ & $\begin{array}{l}\text { - Open season, } 1 \text { December 1995-31 May } 1996 \text { for mobile } \\
\text { gear; fishing prohibited one day per week (state choice) } \\
\text { Open season, 1 January-31 May } 1996 \text { for fixed gear } \\
\text { (traps) } \\
\text { - } \quad \text { Continuation of mesh regulations } \\
\text { - Finfish excluder devices required }\end{array}$ \\
\hline
\end{tabular}


shrimp fishery over time". The Section further stated its intent to allow a northern shrimp fishery through the mechanism of an annual open season, with the following regulatory measures endorsed as appropriate:

1. Gear limitations, conforming to the uniform mesh size regulation $(44.5 \mathrm{~mm}$ or 1.75 inches stretched mesh in body and codend);

2. Seasonal limitations, open season to be set within a 183 day window beginning not earlier than 1 December and ending not later than 31 May for any one year, to be set after considering recommendations of the Technical Committee;

3. Possession limitations, i.e. within season only, count per pound $<60$ with $10 \%$ tolerance; and

4. Information collection provisions, i.e. determination of participants, dealer and processor reporting, and dockside and sea sampling.

The Section further indicated its intent to periodically re-examine mesh size "as management programs for other small mesh net fisheries ... are developed and implemented".

The above measures, and biological and socioeconomic research requirements for management, are embodied in the "Interstate Fishery Management Plan for the Northern Shrimp (Pandalus borealis Kroyer) Fishery in the Western Gulf of Maine" rewritten from the 1979 version (McInnes, 1986). This Plan has remained in effect until the present time.

The management strategy employed by the Section during the 1980 s appears to have been effective. The consequences of the 1970s collapse, and the need for a conservative approach to rebuild the resource, were not lost on the Section; and the management actions taken during the 1980s were consistent with the Section's goals. Management during these years was also greatly assisted by initiation of the State-Federal northern shrimp survey, which provided the capability to accurately monitor incoming recruitment and mortality rates and to advise the Section accordingly; and under conditions which developed in the 1980s it was possible to manage the resource effectively utilizing annual index-based assessments.

The mid-1980s witnessed a resurgence of the resource, accompanied by relatively low $F$ and exploitation rates. Improved recruitment, particularly from the strong 1982 year-class, made it possible for the Committee to advise, and the Section to implement, a gradual extension of the open season for 1982-85 culminating in the maximum duration allowable (1 December-31 May) for the 1986 and 1987 seasons (Table 5). Fishing mortality and exploitation rates averaged about 0.2 during the mid1980 s, well below levels thought to be sustainable in other areas.

The 1987 assessment indicated a $30 \%$ reduction in biomass coincident with the passage of the 1982 year-class through the fishery, and consequently the Committee advised a reduced season for 1988 , although the maximum allowable was retained. The 1987 year-class, however, proved to be comparable in size to the strong 1982 year-class, and accordingly the Committee again advised the maximum for the 1989-91 seasons, adopted in each case by the Section. The 1991 and 1992 assessments, however, revealed a sharp decline in abundance coincident with the passage of the 1987 year-class through the fishery, and accordingly the Committee advised a reduced season for 1992 and 1993 (January-March). The Section reduced the season in both cases (midDecember to 15 May and 30 April, respectively). The practice of "days off", i.e. one day per week in which fishing was prohibited, was also initiated for the 1992 season, and continued in 1993 (Table 5).

The 1993 assessment indicated poor prospects for the 1994 season, but there was evidence for a strong 1992 year-class during the 1993 summer survey; and an above average 1993 year-class was detected in 1994. The Committee advised a January-March season for both 1994 and 1995 to protect these yearclasses. The Section agreed to a reduced season for 1994 but increased it in 1995 (mid-December to midApril and December through April, respectively) with a one day per week closure in the 1995 season (Friday or Sunday, depending on the state choice). For 1996, recruitment of these year-classes led to recommendation for the maximum allowable season under the policy statement.

In 1993, the Atlantic Coastal Fisheries Cooperative Management Act (ACFCMA) was enacted, which gave the ASMFC considerably more influence over management of coastal marine resources than it had previously. The ACFCMA obligated individual States to implement ASMFC-approved measures, and it authorized the Secretary of Commerce to declare a moratorium on a State's fishery for failure to comply 
with ASMFC plan provisions. It also required the establishment of "Advisory panels" that would contribute to management including plan development. This both formalized industry input to the Section and set the stage for a more confrontational relationship between the Committee and industry.

Another development in the early- to mid-1990s, with potential far-reaching consequences for the shrimp fishery, involved implementation of very restrictive effort controls on the groundfish fishery through Amendments 5 and 7 to the Multispecies Fishery Management Plan for Atlantic Groundfish. Amendment 7, which took effect in July of 1996, provided for an accelerated effort reduction schedule creating the potential for a significant redirection of groundfish effort to the shrimp fishery. In turn, this resulted in a concomitant need for more intensive shrimp management based on more quantitative assessments. Accordingly, the Committee began to develop an analytical ( $\mathrm{C}-\mathrm{S}$ model) assessment in 1996.

The autumn 1996 assessment, as expected, indicated good prospects for the 1997 fishery; but the 1994 and 1995 year-classes were observed to be substantially weaker than their immediate predecessors. As well, effort had increased rapidly in 1995 and 1996, and landings had reached 9200 tons during the 1996 season - a level not seen since the early1970s. The Committee advised restriction of effort in December to protect ovigerous females and in April and May to protect the 1994 to 1996 year-classes. The Section opted for a 1 December-27 May season, reduced by blocks of time rather than the one-dayper-week approach.

The first analytical assessment, completed and peer-reviewed at the $25^{\text {th }}$ Northeast Regional Stock Assessment Workshop (SAW) in July 1997, revealed sharp increases in $F$ and reductions in biomass in 1996 (Cadrin et al., MS 1998). The update of this assessment for the November 1997 meeting of the Section, including 1997 data, corroborated these findings and showed a further increase in $F$ to 0.85 in the 1997 season - well over twice the 1985-95 average of 0.34 , which yield and eggs-per-recruit modeling indicated to be sustainable. The 1996 yearclass was estimated to be of about average size, but the 1994 and 1995 year-classes were clearly weak. Biomass had declined by over $50 \%$ since the beginning of the 1996 season. Accordingly, the Committee recommended a February-March season, which would reduce $F$ to at or below the $1985-95$ average. This translated into a recommended catch of 2000 tons.

Release of the July assessment (NEFSC MS 1997) led to a series of meetings by the Advisory Panel which resulted in a proposal for a season of 105 days for the mobile gear fleet (8 December-22 May, excluding 25-31 December and 16-31 March, and all weekends except 14-15 March). Trap fishermen would fish from 1 January to 15 March, Sundays excepted. In language reminiscent of industry testimony in the mid-1970s, the Panel argued that the proposed two-month season would result in a collapse of the shrimp industry infrastructure, and that the proposed 105 day season would be the absolute minimum needed for the industry to remain viable. There was interest in exploring use of $40 \mathrm{~mm}$ square-mesh trawl gear as an alternative to effort restrictions, but when the Committee presented evidence indicating that a larger mesh size would be needed to achieve comparable selectivity to that of existing uniform mesh trawls, the issue was dropped. In any case, the Advisory Panel's proposal was accepted at the November 1997 meeting of the Section. In the ensuing 1998 fishing season almost 4000 tons were landed - double the recommended level, and stock biomass continued to decline.

The 1998 assessment presented to the Section in November of that year indicated a further decline in biomass to 6200 tons (the lowest in the time series, and well below half of the 1984-98 average). Fishing mortality in the 1998 season had declined somewhat (to 0.57 ), but remained well above the recommended sustainable level. Further, 1998 summer survey results corroborated the weakness of the 1994 and 1995 yearclasses, and indicated the 1997 year-class to be one of the poorest on record. Given this situation, the Committee advised limiting the 1999 fishing season to a rebuilding level totaling no more than 40 days during the February-March period. This translated into a reduction in $F$ of more than 50\% from 1997 levels, and a recommended catch of 1200-1 800 tons (NSTC, MS 1998).

Again, the Advisory Panel had been made aware of the Committee position, and had developed its own proposals prior to the November meeting. The Advisory Panel again recommended a 105-day season, for the following reasons: reduced incentive to fish because of lower abundance; poorer market conditions; and anticipated worse than normal weather conditions. The ensuing debate, although dominated by industry, 
indicated more appreciation for the status of the resource than in 1998; and the resulting season of 90 days was approved by a 2-1 vote. The Committee warned that this action would lead to further declines in abundance and reduced prospects for stock recovery.

\section{Discussion}

Among the northern shrimp stocks of the world, the Gulf of Maine stock has long been considered a special case. Apollonio et al. (1986) concluded that this resource, because of its geographic location and its inherent susceptibility to environmental influences, would be inherently unstable. Being the southernmost northern shrimp stock in the North Atlantic, one would expect temperature to play an important role in resource trends; and the inverse correlation between abundance and sea-surface temperature reported by Dow (1977a) has since been corroborated (Richards et al. MS 1996 and other studies). This stock has in fact been one of the few examined by Myers (1998) for which previous relationships between environmental influences and abundance trends remained statistically significant when re-examined. Myers found this result to be "... consistent with longestablished patterns of the behavior of species at the limit of their range. That is, abiotic factors should be more important at the limit of a range ... where their influences will generally be simple enough to be understood". [Or identified; the precise mechanisms involved for Gulf of Maine shrimp remain unclear].

The events of the past half century leave little doubt as to the importance of temperature in determining historical trends in abundance. Record high sea-surface temperatures during the early-1950s as recorded at Boothbay Harbor were accompanied by complete failure of the fishery from 1954 to 1957, in spite of relatively modest levels of fishing effort; and conversely, the cold temperature years of the earlyto mid-1960s appear to have been very favorable for recruitment with concomitant rapid increases in abundance and record landings from 1969 to 1972. Even more pronounced cold temperature periods show up in the Boothbay Harbor record earlier in the century; but there is little or no information on trends in abundance for these years. More recently, analyses by Richards et al. (MS 1996) have demonstrated the apparent importance of sea-surface temperature conditions during the larval planktonic stage. Here it is interesting to note that the significant recruitment events during the last two decades coincided with normal to below normal spring sea-surface temperature anomalies (Fig. 18). As well, they coincided with relatively high spawning biomass levels (Richards et al., MS 1996; Tables 3 and 4).

In contrast, the 1970 s collapse was more problematical, as it occurred during a period of warming temperatures and high, and increasing, levels of $F$. As abundance declined, the ensuing controversy tended to focus on an appropriate management response given the aforementioned observations on relationships between temperature and historical trends in abundance. The Committee argued for a conservative approach, first to arrest declining abundance and then to halt exploitation completely when declines continued. That environmental conditions were unfavorable was understood; but this justified a more conservative, rather than a less conservative approach. The opposing argument was that in view of past events and geography temperature effects would be overriding and that overfishing, if it was occurring at all, would be acting simply to accelerate natural trends. Recruitment failure had occurred under unusually warm temperature conditions in the 1950s and would be expected to occur again under existing circumstances probably irrespective of what management did. Testimony to this effect was initially very effective and had much to do with failure to formulate a more conservative management response during the mid-1970s and the reopening of a winter fishery in 1979.

While the historical evidence of the 1950s and 1960 s is clear, there is considerable evidence to support the argument that overfishing played a major role in the 1970s collapse. Fishing mortality levels, already about 0.7 in the late-1960s, rose to about 1.5 from 1973 to 1977 ; and in contrast to the historical winter fishery, both adults and juveniles were being heavily exploited throughout the year over a wider area, including during the spawning season. The importance of spatial dynamics of stock structure and fishing processes has been well acknowledged but often ignored, and the deprivation of geographic harvest refugia with expansion of a fishery can have dangerous effects (Orensanz et al., 1998). In the present situation spawning concentrations that had previously been untargeted appear to have been heavily impacted. The effects of this cannot have been beneficial. The tangible evidence as evidenced by sampling of commercial landings is that many millions of shrimp not only failed to survive to the ovigerous stage but failed to spawn as males during summer as well. Conversely, following closure of the 
fishery in the late-1970s, and under moderate levels of exploitation restricted to winter and spring during the 1980s and early-1990s, the resource recovered and several strong year-classes were produced.

Results of yield-per-recruit and eggs-per-recruit modeling, and data from the 1970s stock collapse, appear to provide useful guidance for estimating sustainable levels of $F$ for Gulf of Maine northern shrimp. Biomass indices from the Maine survey and the biomass dynamics model suggest that biomass began to decline in 1968. Estimates of $F$ from survey length frequencies averaged 0.7 from 1968 to 1970 , subsequently increasing to 1.5 during the mid-1970s (Clark and Anthony, 1981; Clark, MS 1982). Estimates of $F$ for 1973-75 from the production model ranged from 0.6 to 1.1. According to an egg per recruit analysis that assumed historical selectivity, spawning potential was reduced to less than $10 \%$ of maximum when $F$ exceeded 0.6 (Cadrin et al., 1999). It appears that the stock was not replacing itself in the late-1960s and early-1970s, and the stock collapsed when egg production was reduced further. In the absence of more reliable stock-recruitment information, $F_{20 \%}(0.63)$ would appear to be a reasonable precautionary overfishing threshold (Goodyear, 1993), which would result in target $F$ s well below 0.6 under the current exploitation pattern (Fig. 16). Stock sizes were relatively stable from 1985 to 1995 , when annual $F$ averaged 0.34 . An $F$ of 0.34 , which corresponds to approximately $35 \%$ of maximum egg production per recruit, may be an appropriate ad hoc management target.

In recent years, the Committee has based its annual advice on achieving reductions in $F$ to 0.34 or lower to rebuild stock biomass. Unfortunately the Section does not have the authority to manage catch directly under the current Fishery Management Plan (FMP). Catch is indirectly managed by setting season lengths that are expected to produce a desired level of catch. As a result, fishery managers have failed to achieve target levels of $F$.

Apollonio et al. (1986) concluded with the observations that the Gulf of Maine northern shrimp population was an inherently unstable one; that abundance is strongly influenced by environmental factors, resulting in an opportunistic life history strategy; and that "Populations such as this one which undergo large scale fluctuations in abundance which are influenced primarily by physical features of the environment do not respond well to attempts to control exploitation". The collapse of the fishery, which occurred in the mid-1950s, supports this position in that it was clearly temperature rather than fishery driven. It is important to note, however, that the temperature levels measured at Boothbay Harbor in those years were unprecedented and were substantially higher than at any other time in this century. The 1970s collapse also was associated with above normal temperatures (Fig. 17); but overfishing was much more strongly implicated and in fact appears to have been overriding. The point was made that the collapse would have occurred irrespective of any management action that could have been taken, but management's response was clearly a case of "too little, too late". Subsequent events reveal that following the 1977 closure the resource did recover and did support a healthy fishery under moderate levels of exploitation until well into the 1990s. It would appear that with careful control of exploitation in space and time, that the resource could continue to do so under conditions normally found in the western Gulf of Maine.

We have attempted to examine historical trends in abundance in relation to both fishery and environmental effects and to propose management options that would enhance prospects for maintaining a reasonably stable fishery. Data from the mid-1970s and the mid-1990s both show that $F$ levels in excess of 0.6 entail the risk of recruitment failure and resultant stock collapse, while more moderate levels (0.3-0.4) on average appear sustainable barring unusual increases in sea-surface temperature such as was observed in the $1950 \mathrm{~s}$. The production model suggests that landings in the order of 3000-4 000 tons are sustainable from a stock biomass of 15000 20000 tons under conditions which have prevailed since the late-1970s (Fig. 19). Further, the historical record shows that a management strategy centered around a winter fishery to maximize recruitment potential and yield per recruit prospects, with direct controls on fishing mortality to ensure that biological targets are not exceeded, provides the best option for maintaining a healthy resource.

\section{Acknowledgments}

We thank everyone who contributed to this paper as former Technical Committee members, as port and sea samplers, and as members of scientific parties during research vessel surveys. Special thanks are due to Vaughn Anthony, former Chief of the Conservation and Utilization Division, NEFSC for his insights and contributions to initial assessments, and to Douglas Grout of the New Hampshire Fish and Game Department for his support as a Technical Committee 


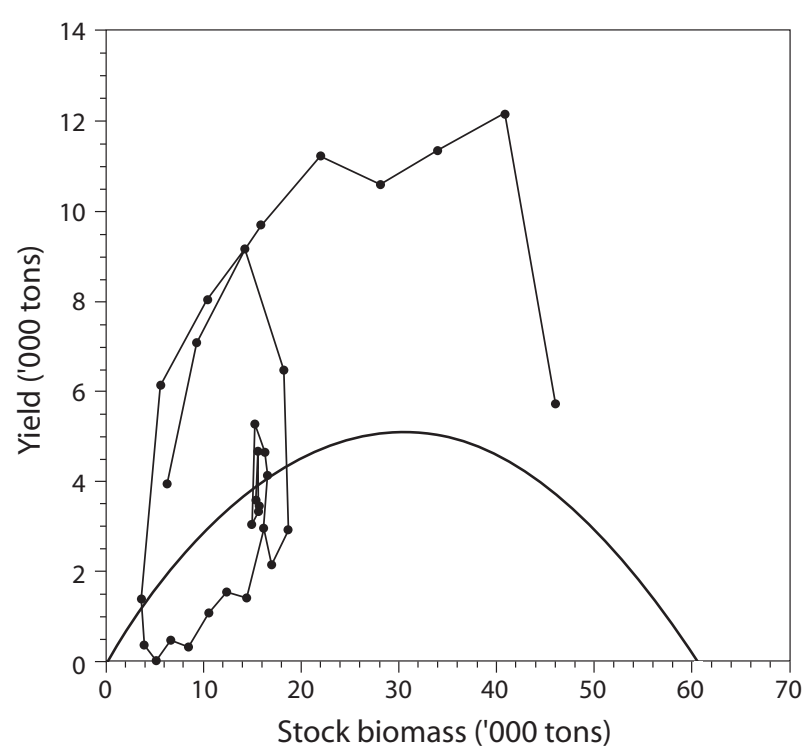

Fig. 19. Biomass dynamics for Gulf of Maine northern shrimp derived from surplus production modeling.

member and colleague. We also thank Elizabeth Holmes and Frances Lanzano of the Resource Evaluation and Assessment Division, NEFSC for computer graphics and typing. We also extend our appreciation to the staff of the NEFSC Resource Surveys Branch, particularly Thomas Azarovitz, Linda Despres, Joseph O'Gorman and John Nelson for their outstanding support in data collection and data base management; and we most sincerely appreciate the efforts of past and current officers and crew members of the NOAA R/Vs Gloria Michelle, Albatross $I V$, and Delaware II. We also thank two anonymous reviewers for their constructive comments.

\section{References}

ANON. MS 1999. Report of the Pandalus Assessment Working Group. ICES C.M. Doc., No. 1999/ACFM: 5, $33 \mathrm{p}$.

ANTHONY, V. C. and S. CLARK. 1978. A description of the northern shrimp fishery and its decline in relation to water temperature. In: Climate and Fisheries, Workshop proceedings, Center for Ocean Management Studies, URI, Kingston, p. 119-121.

APOLlONIO, S., and E. E. DUNTON, JR. 1969. The northern shrimp, Pandalus borealis, in the Gulf of Maine. Completion Rept., ME Dept. Sea and Shore Fisheries, Proj. 3-12-R, 81 p.

APOLLONIO, S, D. K. STEVENSON and E. E. DUNTON, Jr. 1986. Effects of temperature on the biology of the northern shrimp, Pandalus borealis, in the Gulf of Maine. NOAA Tech. Rep. NMFS 42, 22 p.

AZAROVITZ, T., S. CLARK, L. DESPRES, and C. BYRNE.
MS 1997. The Northeast Fisheries Science Center bottom trawl survey program. ICES C.M. Doc., No. 1997/Y:33, $21 \mathrm{p}$.

BlotT, A. J., P. J. DiOdATI, S. H. CLARK, D. B. SAMPSON, and D. F. SCHICK. MS 1983. Development of a new research trawl for northern shrimp, Pandalus borealis, in the Gulf of Maine. ICES C.M. Doc., No.1983/B:21, 6 p.

BRUCE, R. A. 1971. The New England shrimp fishery. In: Proceedings, conference on the Canadian shrimp fishery. Can. Fish. Rep. 17: 257-274.

BURNS, T. S., R.SCHULTZ, and B.E.BROWN. 1983. The commercial catch sampling program in the northeastern United States. In: Sampling commercial catches of marine fish and invertebrates. W.G. Doubleday and G. Rivard (eds.). Can. Spec. Publ. Fish. Aquat. Sci., 66: 82-95.

CADRIN, S. X., D. F. SCHICK, D. McCARRON, S. H. CLARK, M. P. ARMSTRONG, B. SMITH, and J. B. O'GORMAN. MS 1998. Gulf of Maine northern shrimp stock assessment. Woods Hole, MA: NOAA/ NMFS/NEFSC. NEFSC Ref. Doc. 98-07, 26 p.

CADRIN, S. X., S. H. CLARK, D. F. SCHICK, M. P. ARMSTRONG, D. McCARRON, and B. SMITH. 1999. Application of catch-survey models to the northern shrimp fishery in the Gulf of Maine. N. Am. J. Fish. Mgt., 19: 551-568.

CLARK, S.H. MS 1982. Assessment and management of the Gulf of Maine northern shrimp (Pandalus borealis) fishery. ICES C. M. Doc., No.1982/K:13, 20 p.

1989. State-Federal northern shrimp survey. In: Proceedings of a workshop on bottom trawl surveys. Azarovitz, T. R., J. McGurrin and R. Seagraves (eds.). ASMFC Spec. Rept., 17: 27-29.

CLARK, S.H., and V. C. ANTHONY. 1981. An assessment of the Gulf of Maine northern shrimp resource. In: Proceedings of the International Pandalid Shrimp Symposium. T. Frady (ed.). University of Alaska Sea Grant Report 81-3, Fairbanks, p. 207-224.

CLARK, S., and G. POWER. MS 1991. By-catch and discard patterns in the Gulf of Maine northern shrimp fishery. Woods Hole, MA: NOAA/NMFS/NEFSC. NEFSC SAW Res. Doc., 12/10.

CLARK, S. H., V. SILVA, E. HOLMES and J. B. O'GORMAN. 2000. Abstract.Observations on the biology and distribution of northern shrimp, Pandalus borealis, in the Gulf of Maine, from research vessel surveys. Poster session prepared for the International Pandalid Shrimp Symposium, Halifax, N. S. Canada, September 8-10, 1999. Journal of Shellfish Research, 19(1): 543-562.

COLLIE, J. S., and M. P. SISSENWINE. 1983. Estimating population size from relative abundance data measured with error. Can. J. Fish. Aquat. Sci., 40: 1871-1879.

CONSER, R. J., and J. IDOINE. MS 1992. A modified DeLury model for estimating mortality rates and stock sizes of American lobster populations. Woods Hole, MA: NOAA/ NMFS/NEFSC. NEFSC Ref. Doc., 14/7.

DOW, R. L. 1963. Fluctuations in Maine shrimp landings. Comm. Fish. Rev., 25(4): 5-6. 
1964. A comparison among selected marine species of an association between sea water temperature and relative abundance. ICES J. Cons., 28(3): 425-431.

1966. A method of forecasting the relative abundance of northern shrimp (Pandalus borealis Kr.) in Maine waters. Comm. Fish. Rev., 28(3): 14-16.

1977a. Effects of climate cycles on the relative abundance and availability of commercial marine and estuarine species. ICES J. Cons., 37(3): 274-280.

1977b. Natural abundance fluctuations in the Maine shrimp fishery. National Fisherman, March.

DUNHAM, W. C., and J. J. MUELLER. 1976. The economic impact of a reduction in shrimp landings under regulated and unregulated programs. Completion Rep., StateFederal Fish Mgt. Prog. Contract No. 03-5-043-343, 49 p.

EFRON, B. 1979. Bootstrap methods: another look at the jackknife. Ann. Stat., 7: 1-26.

FRECHETTE, J., and S. S. M. LABONTE. 1981. Biomass estimate, year-class abundance and mortality rates of Pandalus borealis in the Northwest Gulf of St. Lawrence. In: Proceedings of the International Pandalid Shrimp Symposium. T. Frady (ed.). University of Alaska Sea Grant Report 81-3, Fairbanks, p. 307-330.

FRECHETTE, J., and D. G. PARSONS. 1983. Report of the shrimp ageing workshop held at Ste. Foy, Quebec, in May and at Dartmouth, Nova Scotia, in November 1981. NAFO Sci. Coun. Studies, 6: 79-100.

FOURNIER, D. A., J. R. SIBERT, and M. TERCEIRO. 1991. Analysis of length frequency samples with relative abundance data for the Gulf of Maine northern shrimp (Pandalus borealis) by the MULTIFAN method. Can. J. Fish. Aquat. Sci., 48: 591-598.

GABRIEL, W. L., M. P. SISSENWINE, and W. J. OVERHOLTZ. 1989. Analysis of spawning stock biomass per recruit: an example for Georges Bank haddock. N. Am. J. Fish. Mgt., 9: 383-391.

GOODYEAR, C. P. 1993. Spawning stock biomass per recruit in fisheries management: foundation and current use. In: Risk evaluation and biological reference points for fisheries management. S. J. Smith, J. J. Hunt, and D. Rivard (eds.). Can. Spec. Publ. Fish. Aquat. Sci., 120, p. 67-81.

HASSELBLAD, V. 1966. Estimation of parameters for a mixture of mixed normal distributions. Technometrics, 8(3): 431-444.

HAYNES, E. B., and R. L. WIGLEY. 1969. Biology of the northern shrimp, Pandalus borealis, in the Gulf of Maine. Trans. Am. Fish. Soc., 98(1): 60-76.

HOWELL, W. H., and R. LANGAN. 1992. Discarding of commercial groundfish species in the Gulf of Maine shrimp fishery. N. Am. J. Fish. Mgt, 12: 568-580.

KALLIO, J. R. MS 1973. Northern shrimp. Unpublished Rept., NMFS, Gloucester.

KENNEY, J. F., A. J. BLOTT, and V.E. NULK. 1992. Experiments with a Nordmore Grate in the Gulf of Maine shrimp fishery. NEFMC Rept., NOAA Award No. NA87EA-H-00052, 26p.

MacISAAC, D. B., and P. DIODATI. 1978. Completion Report: monitoring of the northern shrimp resources. MA Div.
Marine Fish., Project NS75-1-MA-(1)-1, 20 p.

McCRARY, J. A. 1971. Sternal spines as a characteristic for differentiating between females of some Pandalidae. J. Fish. Res. Board Can., 28: 98-100.

McINNES, D. 1986. Interstate fishery management plan for the northern shrimp (Pandalus borealis Kroyer) fishery in the Western Gulf of Maine. ASMFC Fish. Mgt. Rept., No. 9, 77 p.

MOHN, R. K., D. G. PARSONS, and L. SAVARD. 1992. Report of Canadian Atlantic Fisheries Scientific Advisory Committee special meeting, Invertebrates and Marine Plants Subcommittee, shrimp management alternatives, December 5-8, 1989, Ottawa, Canada. Can. Tech. Rep. Fish. Aquat. Sci, 1884, 30 p.

MYERS, R. A. 1998. When do environment-recruitment correlations work? Rev. Fish Biol. Fish., 8: 285-305.

NEFSC (Northeast Fisheries Science Center). MS 1997. Northern shrimp advisory report. In: [Report of the] 25th Northeast Regional Stock Assessment Workshop (25th SAW) Public Review Workshop. Woods Hole, MA:NOAA/NMFS/NEFSC. NEFSC Ref. Doc. 97-15, p. 22-24.

NSSC (Northern Shrimp Scientific Committee). 1979. (Revised) Northern shrimp management plan and environmental impact statement. NMFS, Fish. Mgt. Opns. Branch, Gloucester, $142 \mathrm{p}$.

NSTC (Northern Shrimp Technical Committee). MS 1994. Assessment report for Gulf of Maine northern shrimp1994. Unpublished Report to ASMFC Northern Shrimp Section, October 1994, 12 p.

MS 1998. Assessment report for Gulf of Maine northern shrimp - 1998. Unpublished report to ASMFC Northern Shrimp Section, $16 \mathrm{p}$.

ORENSANZ, J. M., J. ARMSTRONG, D. ARMSTRONG, and R. HILBORN. 1998. Crustacean resources are vulnerable to serial depletion - the multifaceted decline of crab and shrimp fisheries in the Greater Gulf of Alaska. Rev. Fish Biol. Fish., 8: 117-176.

PRAGER, M. H. 1994. A suite of extensions to a nonequilibrium surplus-production model. Fish. Bull., U.S., 92: 374-389.

1995. User's manual for ASPIC: a stock-production model incorporating covariates. SEFSC, Miami. Miami Laboratory Document MIA-92/93-55.

RASMUSSEN, B. 1953. On the geographical variation in growth and sexual development of the deep-sea prawn (Pandalus borealis kr.). Norweg. Fish. and Mar. Invest. Rep., 10(3): 1-160.

RICHARDS, A., M. FOGARTY, S. CLARK, D. SCHICK, P. DIODATI, and B. O'GORMAN. MS 1996. Relative influence of reproductive capacity and temperature on recruitment of Pandalus borealis in the Gulf of Maine. ICES C. M. Doc., No. 1996/K:13, 7 p.

RIESER, A., and N. ZIEGLER. 1982. Regional fisheries regulation under the Atlantic States Marine Fisheries Compact: promising model or unworkable scheme? Territorial Sea, 2(1): 1-7.

RINALDO, R. G. 1973. Northern shrimp - assessment of some population parameters. Completion Rept., P.L. 88- 
309, Proj. 3-117-R, 42 p.

1981. Population assessment of the northern shrimp, Pandalus borealis (Kroyer) in the Gulf of Maine, 1965 to 1975 . Ph.D. thesis, University of Maine, Orono, $210 \mathrm{p}$.

SCATTERGOOD, L. W. 1952. The northern shrimp fishery of Maine. Comm. Fish. Rev., 14(1): 1-16.

SCHICK, D. F. MS 1991. Pandalid shrimp distribution relative to bottom type and availability to commercial and research trawls in the Gulf of Maine. ICES C.M. Doc., No.1991/K:8, 7 p.

SHEPHERD, J. G. 1987. A weakly parametric method for estimating growth parameters from length composition data. In: Length based methods in fisheries research. Pauly, D. and G. R. Morgan (eds.), ICLARM Conf. Proc. 13. Int. Cent. Living Aquat. Res. Manage. Manila, Philippines and Kuwait Inst. Sci. Res., Safat, Kuwait, p. 113-119.

SHUMWAY, S. E., H. C. PERKINS, D. F. SCHICK, and A. P. STICKNEY. 1985. Synopsis of biological data on the pink shrimp, Pandalus borealis Kroyer 1838. NOAA Tech Rep. NMFS 30, 57 p.

SINCLAIR, A., D. GASCON, R. O'BOYLE, D. RIVARD, and S. GAVARIS. MS 1990. Consistency of some northwest Atlantic groundfish assessments. NAFO SCR Doc., No. 96, Serial No. N1831, 35 p.

STICKNEY, A. P. 1978. A previously unreported peridinian parasite in the eggs of the northern shrimp, Pandalus borealis. J. Invertebr. Pathol., 32: 212-215.

MS 1980. Changes in the fecundity of northern shrimp, Pandalus borealis, in the Gulf of Maine, 19631979. ME Dept. Marine Resources, Res. Ref. Doc., $80 / 11$.

1981. Laboratory studies on the development and survival of Pandalus borealis eggs in the Gulf of Maine.
In: Proceedings of the International Pandalid Shrimp Symposium. T. Frady (ed.), University of Alaska Sea Grant Report 81-3, Fairbanks, p. 395-405.

STICKNEY, A. P., and H. C. PERKINS 1977. Environmental physiology of commercial shrimp, Pandalus borealis. Completion Rep., ME Dept. Marine Resources, Proj. 3-202-R, $78 \mathrm{p}$.

1979. Environmental physiology of northern shrimp, Pandalus borealis. Completion Rep., ME Dept. Marine Resources, Proj. 3-277-R, 66 p.

TERCEIRO, M., and J. S. IDOINE. 1990. A practical assessment of the performance of Shepherd's length composition analysis (SRLCA): application to Gulf of Maine northern shrimp Pandalus borealis survey data. Fish. Bull., U.S., 88: 761-773.

THOMPSON, W.F., and F. H. BELL. 1934. Effect of changes in intensity upon total yield and yield per unit of gear. Rept. Int. Fish. Comm., 8: 7-49.

TOMLINSON, P. K. 1971. Program name - NORMSEP. Programmed by V. Hasselblad. In: Computer programs for fish stock assessment. N. J. Abramson (compiler). FAO Fish. Tech. Pap., 101.

U.S. DEPT. INTERIOR 1954. M/V DELAWARE exploratory surveys, Cruise Reports 32, 33. (Files, NEFSC, Woods Hole Laboratory).

1955. M/V DELAWARE exploratory surveys, Cruise Reports 3, 4, 6. (Files, NEFSC, Woods Hole Laboratory).

WALFORD, L. A. 1948. Notes on shrimp fishing along the New England coast. U.S. Fish. Wildl. Serv., Fish. Leaflet, No. 318, 4 p.

WIGLEY, R. L. 1973. Fishery for northern shrimp, Pandalus borealis, in the Gulf of Maine. Mar. Fish. Rev., 35 (34): 9-14. 